Prepared in cooperation with the National Park Service

\title{
Geology Along Mosca Pass Trail, Great Sand Dunes National Park and Preserve, Colorado
}

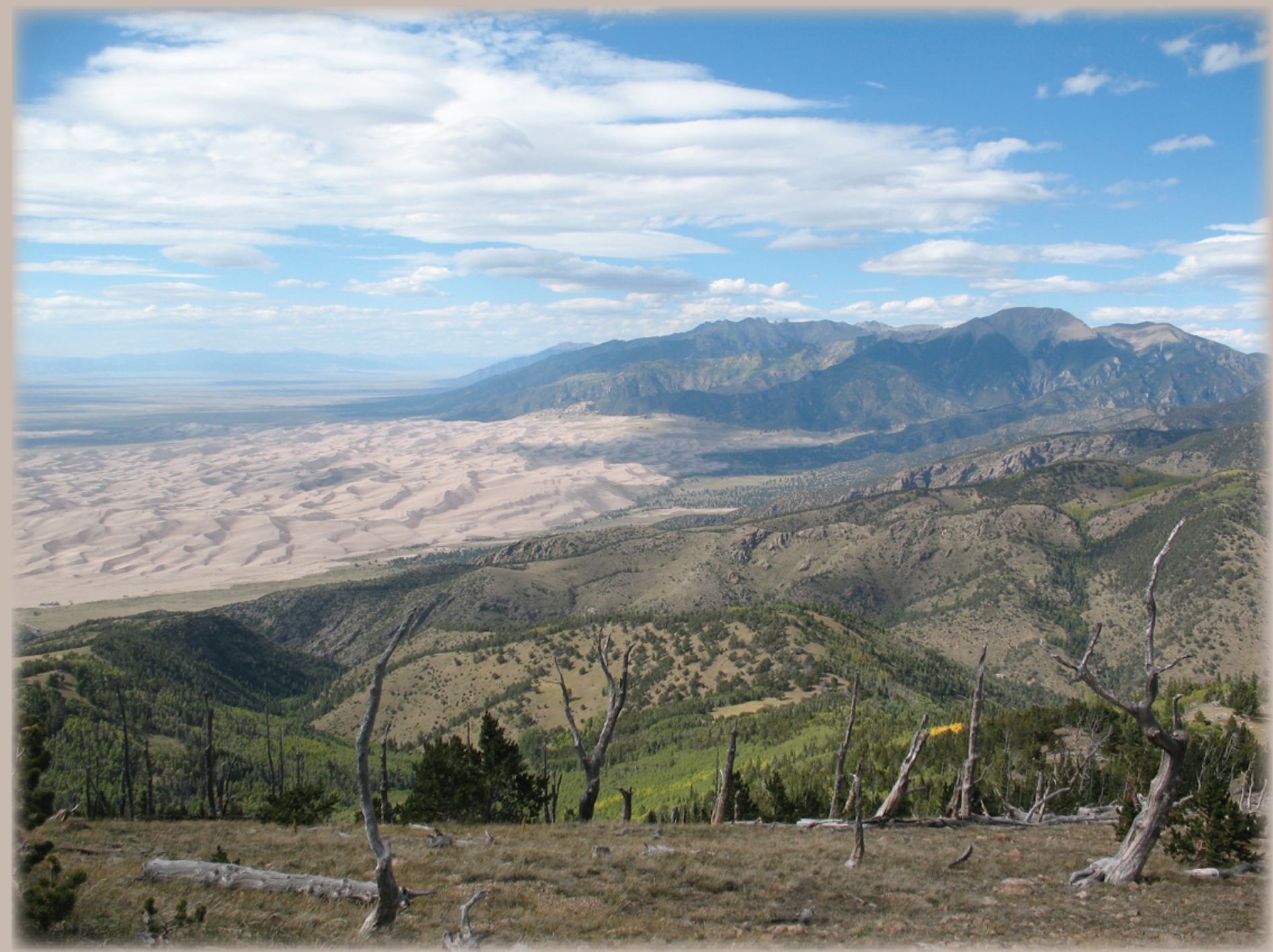

Circular 1374

U.S. Department of the Interior

U.S. Geological Survey 


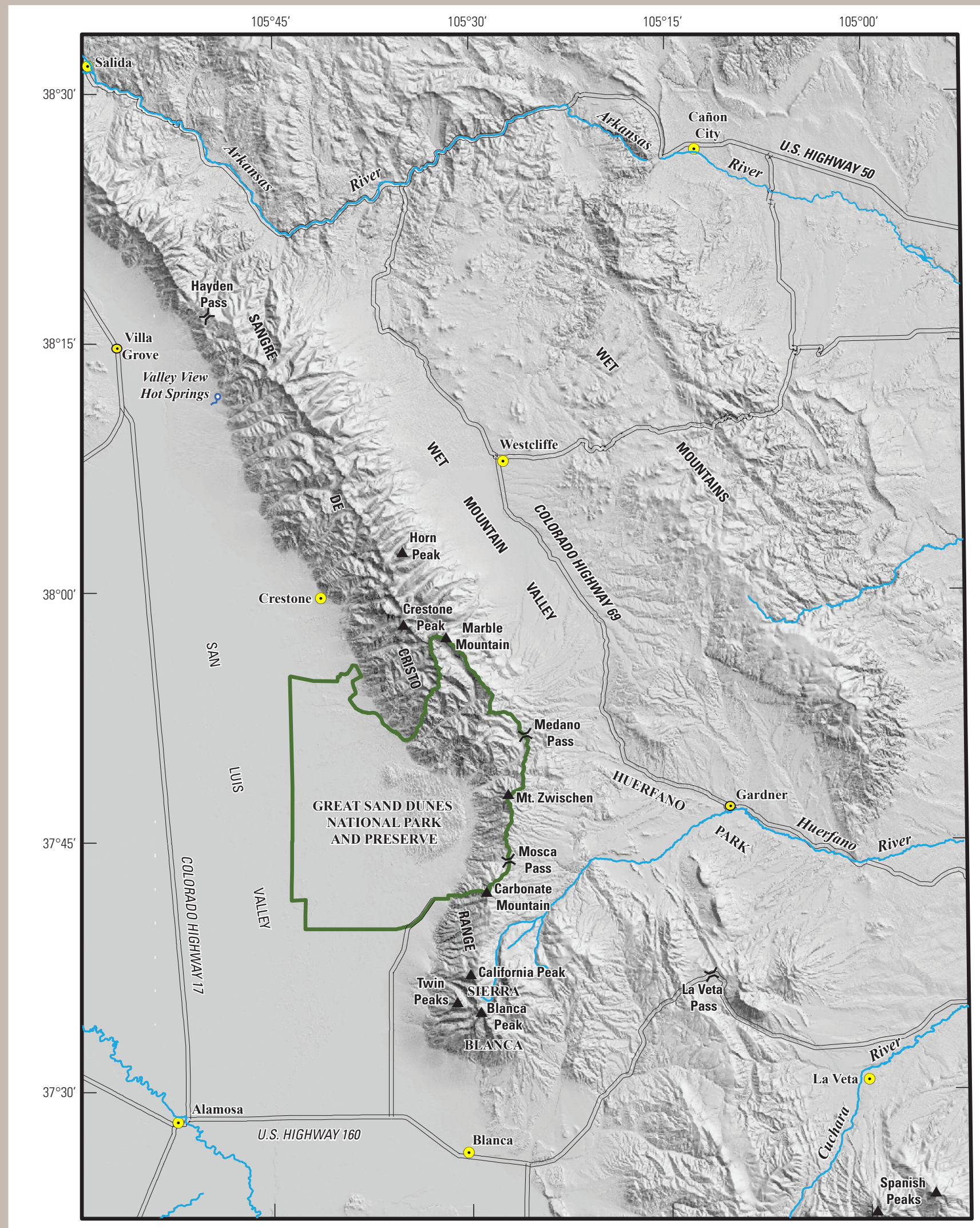

Index map. 


\section{Geology Along Mosca Pass Trail, Great Sand Dunes National Park and Preserve, Colorado}

By David A. Lindsey, Terry L. Klein, Andrew Valdez, and Robert J. Webster

A Trail Guide and Introduction to the Geology of the Sangre de Cristo Range East of Great Sand Dunes

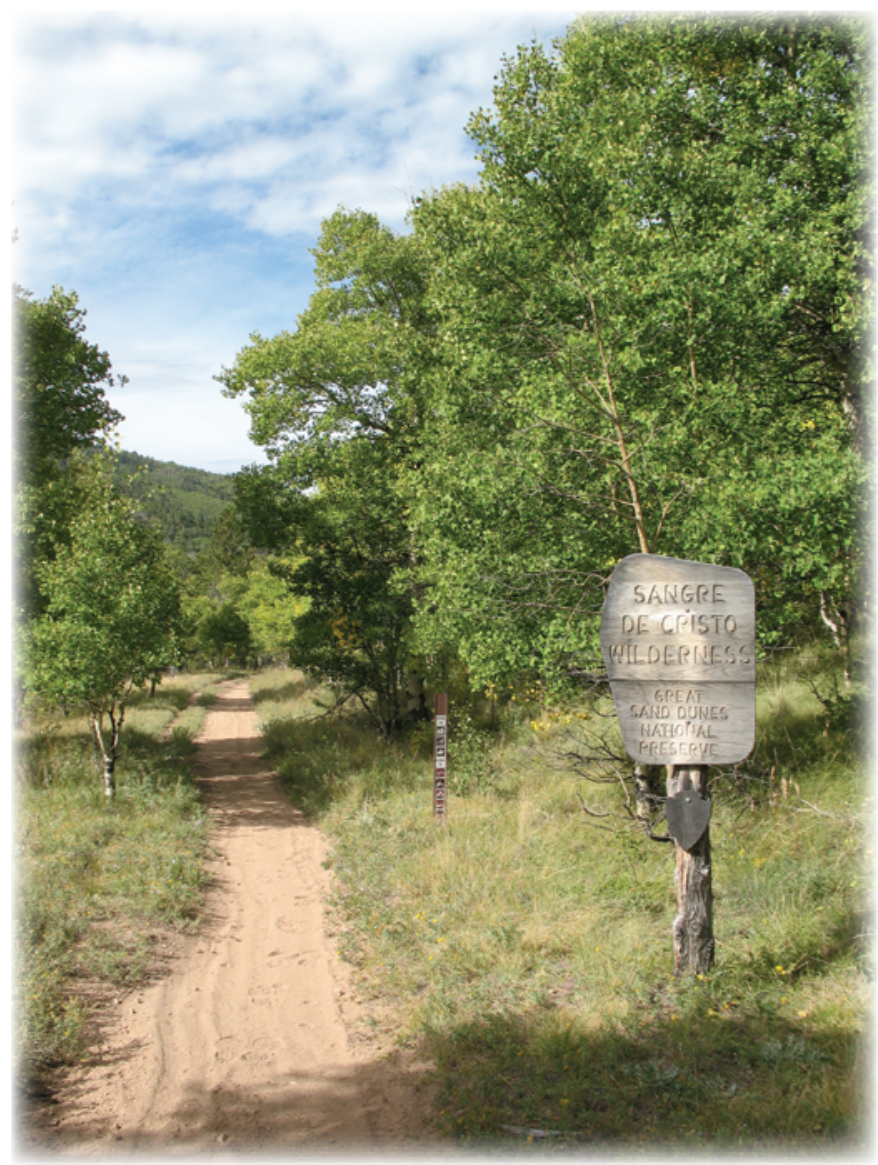

Prepared in cooperation with the National Park Service

Circular 1374 


\section{U.S. Department of the Interior \\ KEN SALAZAR, Secretary \\ U.S. Geological Survey \\ Marcia K. McNutt, Director}

U.S. Geological Survey, Reston, Virginia: 2012

For more information on the USGS - the Federal source for science about the Earth, its natural and living resources, natural hazards, and the environment, visit http://www.usgs.gov or call 1-888-ASK-USGS.

For an overview of USGS information products, including maps, imagery, and publications, visit http://www.usgs.gov/pubprod

To order this and other USGS information products, visit http://store.usgs.gov

Any use of trade, product, or firm names is for descriptive purposes only and does not imply endorsement by the U.S. Government.

Although this report is in the public domain, permission must be secured from the individual copyright owners to reproduce any copyrighted materials contained within this report.

Suggested citation:

Lindsey, D.A., Klein, T.L., Valdez, Andrew, and Webster, R.J., 2012, Geology along Mosca Pass Trail, Great Sand Dunes National Park and Preserve, Colorado: U.S. Geological Survey Circular 1374, 18 p. 


\section{Contents}

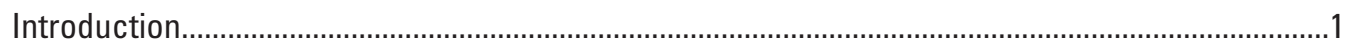

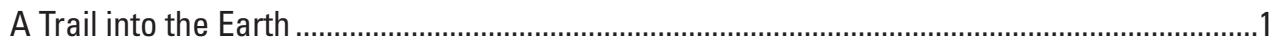

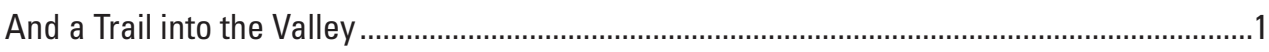

About Technical Terms ......................................................................................................

Geologic Setting................................................................................................................

Range-Boundary Faults, Alluvial Fans, and Pediments.........................................................

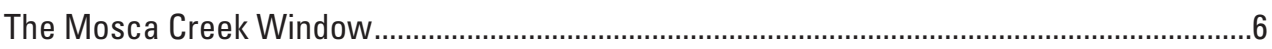

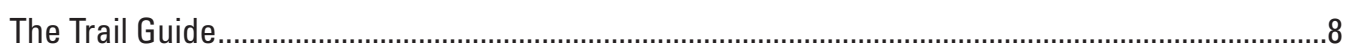

Locating Yourself on the Trail............................................................................................

Rocks Along Montville Nature Trail ......................................................................................

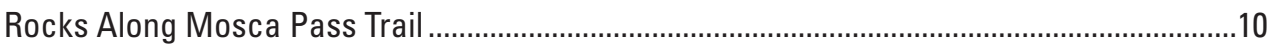

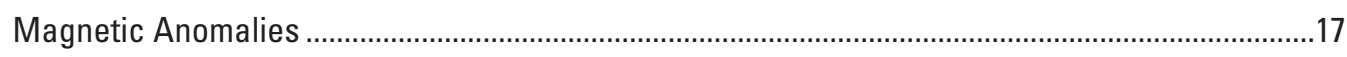

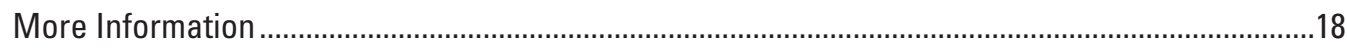

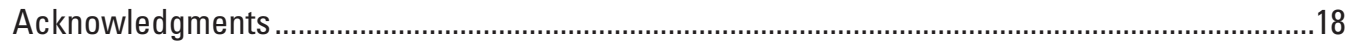

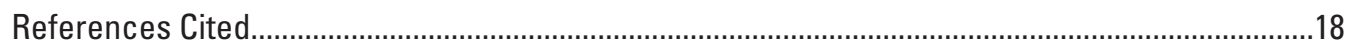

\section{Figures}

1. Composite photograph of the Sangre de Cristo Range, looking north from the

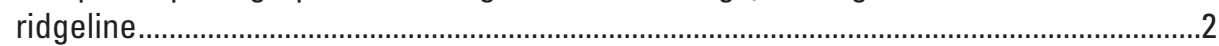

2. Geologic map of the region around the Mosca Pass Trail .................................................3

3. Geologic cross sections through the Sangre de Cristo Range at Mosca Pass showing $(A)$ The present-day range and $(B)$ The big picture 70-60 million years ago.

4. Photograph showing young fault boundary on the southwest side of the Sierra Blanca.

5. Photograph showing old fault boundary on the east side of the range between Mosca Pass and Medano Pass.

6. Topographic map showing location of points of geologic interest along the Montville Nature Trail and the Mosca Pass Trail

7-15. Photographs at points on the Mosca Pass Trail:

7. At point 1: Montville Nature Trail: $(A)$ Light-colored igneous dike and brown thrust breccia, $(B)$ Red sandstone east of dike, and $(C)$ Slickensides in light-colored igneous dike

8. At point 2: $(A)$ Looking east along trail, $(B)$ Slickensides of greenish chlorite and white quartz on sandstone block, and $(C)$ Looking west at sandstone cliffs above fault

9. At point 3: $(A)$ Looking west at trail in notch cut through sandstone, $(B)$ Broad fold in Minturn Formation sandstone bed along the trail, and $(C)$ Small fault with slickensides

10. At point 4: $(A)$ Looking east along trail, $(B)$ Near-horizontal slickensides in outcrop showing movement parallel to Laramide compression direction, and $(C)$ Sandstone beds with white quartz granules of lower Minturn Formation. 
11. At point 5: $(A)$ Looking west along trail at a fault breccia and $(B)$ Close-up showing fractures and rotated blocks

12. At point 6: $(A)$ Looking west at reverse fault and $(B)$ Deformation shown by closely spaced fractures filled with quartz

13. At point 7: Looking east along trail at exposures of steeply dipping sandstone beds.

14. North of point 8: Mosca Creek thrust marked by gneiss breccia above sandstone of Minturn Formation.

15. At point 9: $(A)$ Breccia zone in gneiss above the Mosca Creek thrust and (B) Gneiss of Twin Peaks pluton immediately above breccia zone.................................16

16. Photograph of Mosca Pass from the east trailhead......................................................17 


\title{
Geology Along Mosca Pass Trail, Great Sand Dunes National Park and Preserve, Colorado
}

\author{
By David A. Lindsey, ${ }^{1}$ Terry L. Klein, ${ }^{1}$ Andrew Valdez, ${ }^{2}$ and Robert J. Webster ${ }^{3}$
}

\section{Introduction}

\section{A Trail into the Earth}

Mosca Pass Trail takes the hiker on a journey into the Earth's crust. Here you can see the results of tremendous tectonic forces that bend and tear rocks apart and raise mountain ranges.

The trail begins near the Sangre de Cristo fault, which separates the Sangre de Cristo Range from the San Luis Valley. The valley is part of the Rio Grande rift, a series of fault basins extending from southern New Mexico to central Colorado, wherein the Earth's crust has been pulled apart during the last 30 million years. Thousands of feet of sediment, brought by streams mostly from the Sangre de Cristo Range, fill the San Luis Valley beneath the Great Sand Dunes.

The trail ends at Mosca Pass overlooking Huerfano Park. The park is part of the larger Raton Basin, formed by compression of the Earth's crust during the Laramide orogeny, which occurred 70-40 million years ago. Massive highlands, the remnants of which are preserved in the Sangre de Cristo Range, were uplifted and pushed over the western side of the Raton Basin. Streams eroded the highland as it rose and filled the Raton Basin with sediment. After the sediment was compacted and cemented to form sedimentary rock, the Huerfano River and other streams began to excavate the basin. Over an unknown but long timespan that probably lasted millions of years, relatively soft sedimentary rocks were removed by the river to form the valley we call "Huerfano Park."

Between the ends of the trail, the hiker walks through an erosional "window," or opening, into red sedimentary rocks overridden by gneiss, a metamorphic rock, during the Laramide orogeny, which is described in more detail in following sections. This window gives the hiker a glimpse

${ }^{1}$ U.S. Geological Survey, MS 973, Box 25046, Federal Center, Lakewood, $\mathrm{CO} 80225$

${ }^{2}$ Great Sand Dunes National Park and Preserve, 11500 Highway 150, Mosca, CO 81146.

${ }^{3}$ OXY USA Inc., 5 Greenway Plaza, Suite 110, Houston, TX 77046. into the Laramide highland of 70-40 million years ago that preceded the present-day Sangre de Cristo Range. The window is the focus of this trail guide. At the east end of the trail, near Mosca Pass, another trail follows the ridgeline south to Carbonate Mountain (Winger and Winger, 2003). Immediately after reaching the first summit above tree line, this trail crosses a narrow valley where red rocks mark an extension of the window across the range. Stunning vistas of the Sangre de Cristo Range extend north to the horizon (fig. 1). The uplifted range stands in sharp contrast to the San Luis Valley on the west and Huerfano Park on the east.

\section{And a Trail into the Valley}

Geology affects geography, and geography affects history. At Mosca Pass the range-boundary faults are close together. Streams have eroded the range to allow passage through low passes and short valleys.

Mosca Pass has long been a gateway to the San Luis Valley because it is one of the shortest routes across the Sangre de Cristo Range (National Park Service, 2011; Harlan, 1976). Indians and Spanish explorers probably crossed the range through Mosca Pass. Here the fur trader Antoine Robidoux crossed from the Great Plains into the Rocky Mountains in the early 19th century. The expeditions of Zebulon Pike in 1807 and John C. Fremont in 1848 crossed the Sangre de Cristo Range in the winter, but they probably went through nearby Medano Pass. After 1870 a toll road crossed the range at Mosca Pass giving access by horse and wagon for commerce and mail into the San Luis Valley. The road washed out during heavy rains in the early 1900s and never fully reopened. Today travelers and commerce from the east use the highway across La Veta Pass to the south. The Mosca Pass Trail is maintained for hikers and horses.

\section{About Technical Terms}

Like any scientific field, geology has its share of technical terms. We attempt to describe and illustrate names of rocks and other features as we follow the trail; look for these descriptions and definitions under "Geologic Setting" and in "The Trail Guide." Inevitably, however, you will come across some terms that we have not described adequately. Rather 


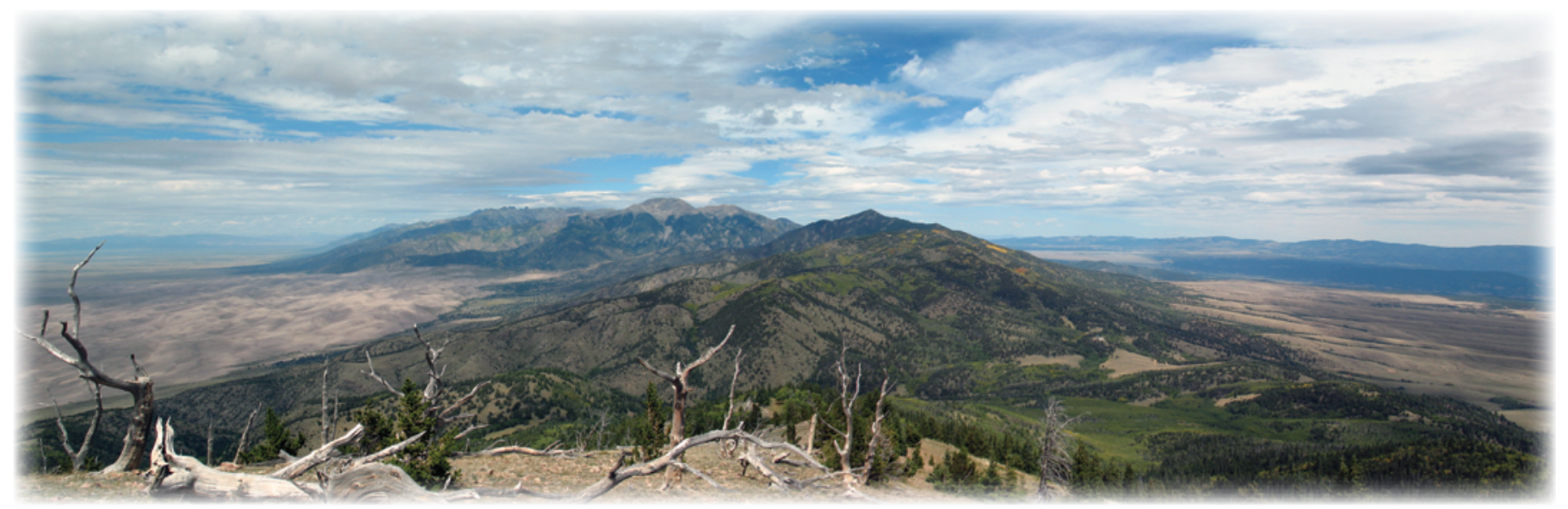

Figure 1. Composite photograph of the Sangre de Cristo Range looking north from the ridgeline summit at tree line—elevation 10,268 feet, about 1.5 miles north of Carbonate Mountain (see index map). The range is delineated by the Sangre de Cristo normal fault on the left and an eroded thrust fault of Laramide orogeny age, on the right; the Great Sand Dunes are on the left and Huerfano Park is on the right. Mosca Creek and Mosca Pass are located in the forested lowlands just beyond the treeless foreground.

than provide yet another glossary at the end of this guide, we encourage you to look for descriptions online or to consult guidebooks with glossaries of geologic terms. The pocket guide "Rocks Above the Clouds" (Reed and Ellis, 2009) has descriptions and pictures of rocks, structures, and other geologic features common to the mountains of Colorado. A geologic time scale (U.S. Geological Survey Geologic Names Committee, 2007) is available online.

\section{Geologic Setting}

\section{Range-Boundary Faults, Alluvial Fans, and Pediments}

Before ascending the trail, study the geologic map (fig. 2) and cross sections (fig. 3). Notice the orientation of the Sangre de Cristo fault in the first cross section (fig. $3 A$ ). It dips west at a high angle, arbitrarily drawn at 60 degrees, although we cannot measure the dip accurately. The west side (hanging wall of fault) has moved down against the east side (footwall of fault). We call such high-angle faults with down-dropped hanging walls "normal faults." In contrast to the Sangre de Cristo fault, the west side (hanging wall) of the boundary fault on the east side of the range has moved up, instead of down like a normal fault. The angle of the fault is arbitrarily shown dipping west 45 degrees near the surface but is interpreted to flatten beneath the Sangre de Cristo Range to the west (fig. $3 A$ ). Where it is exposed a few miles to the north, the east-side boundary fault dips west less than 20 degrees. We call such low-dipping faults "thrusts." Thrust faults dip at low angles, typically less than 45 degrees, and usually bring older rocks over younger rocks. If the dip is greater than 45 degrees, the same fault is called a "reverse fault." Another line of evidence for westward flattening of the east-side boundary fault beneath the Sangre de Cristo Range is from magnetic anomalies, to be discussed later.

The cross section in figure $3 A$ represents the Sangre de Cristo Range as it appears at Mosca Creek now. Figure $3 B$ shows a big-picture cross section through the range at about 70-60 million years ago. The Sangre de Cristo normal fault has been removed from the cross section because it formed later, after the time represented by the cross section in figure 3B. However, at 70-60 million years ago, compression of the Earth's crust was forming the east-side boundary fault. The boundary fault separated a highland (labeled "Laramide highland" in fig. $3 B$ ) and an adjacent basin (labeled "Raton Basin") to the east. As the highland rose, it was eroded by streams that filled the basin with sediment. Later, after about 55 million years ago, another highland centered over the present Wet Mountains (see index map) began to rise, shedding additional sediment into the northwestern part of the Raton Basin from the northeast.

The topography of the west side of the Sangre de Cristo Range is more rugged than the east side of the range. This difference in topography reflects the different ages of the faults on the west and east sides of the range. On the west side, scarps of the Sangre de Cristo fault cut alluvium close to the range front and large flatiron-shaped surfaces (called "faceted spurs") cut off the ends of ridges (fig. 4). Segments of the range front are straight and abrupt. In contrast, the range front on the east side lacks fault scarps in alluvium, does not have faceted spurs, and is irregular and subdued (fig. 5). The Sangre de Cristo fault on the west side of the range formed during the time of Rio Grande rifting (from 30 million years ago to the present); the east-side boundary fault is older and assigned to the Laramide orogeny (70-40 million years ago). 


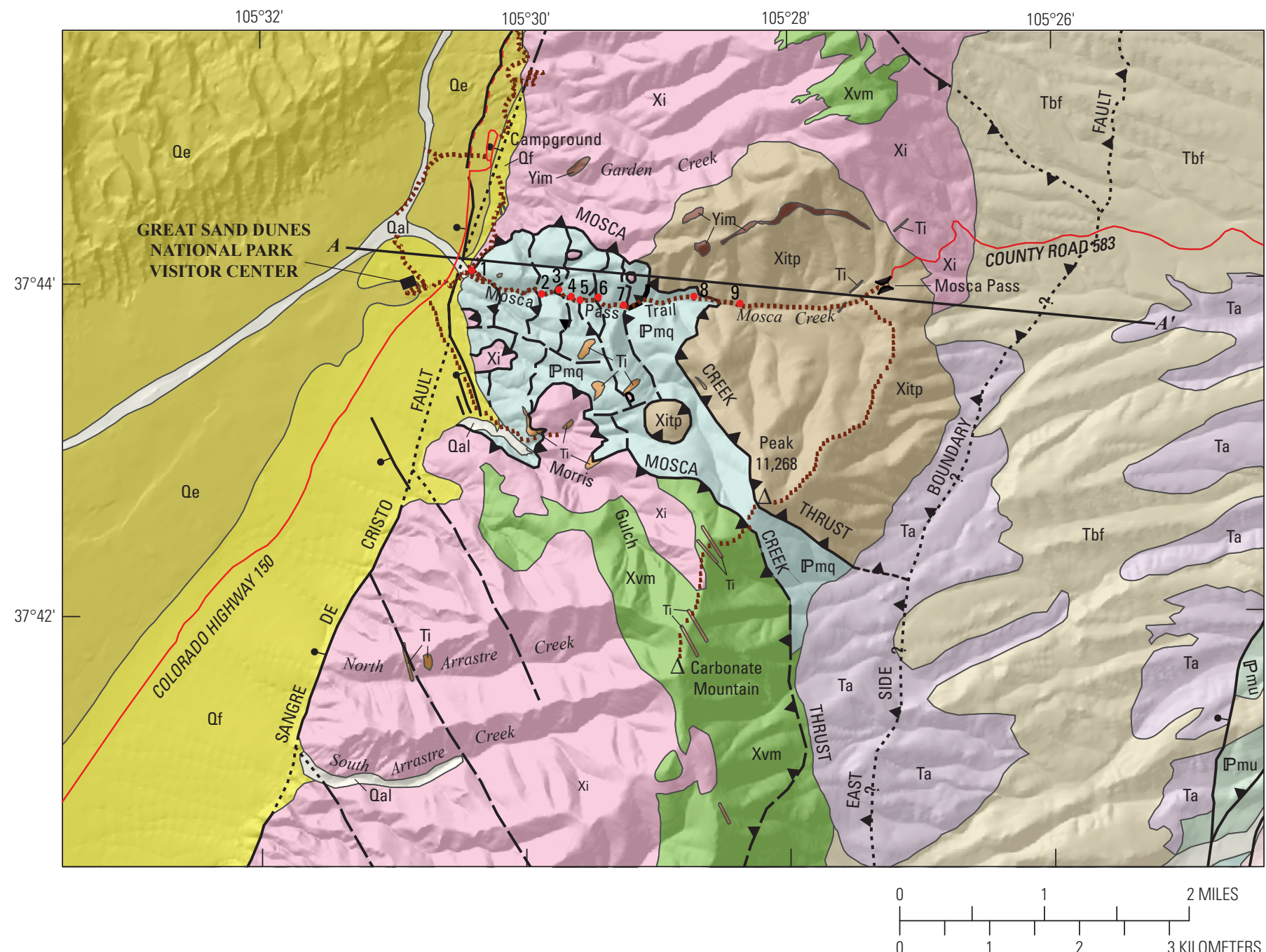

EXPLANATION

\begin{tabular}{|c|c|}
\hline \multicolumn{2}{|c|}{ Quaternary } \\
\hline Qal & Alluvium \\
\hline Qe & Eolian sand \\
\hline af & Alluvial fan deposits \\
\hline & ertiary \\
\hline Tbf & Basin fill deposits \\
\hline Ta & Andesite flows \\
\hline$\overline{\mathrm{Ti}}$ & Intrusions (dikes and plugs) \\
\hline & 'ennsylvanian \\
\hline Pmu & Minturn Formation, undivided \\
\hline Pmq & $\begin{array}{l}\text { Minturn Formation, lower part } \\
\text { (quartz-pebble redbeds) }\end{array}$ \\
\hline
\end{tabular}

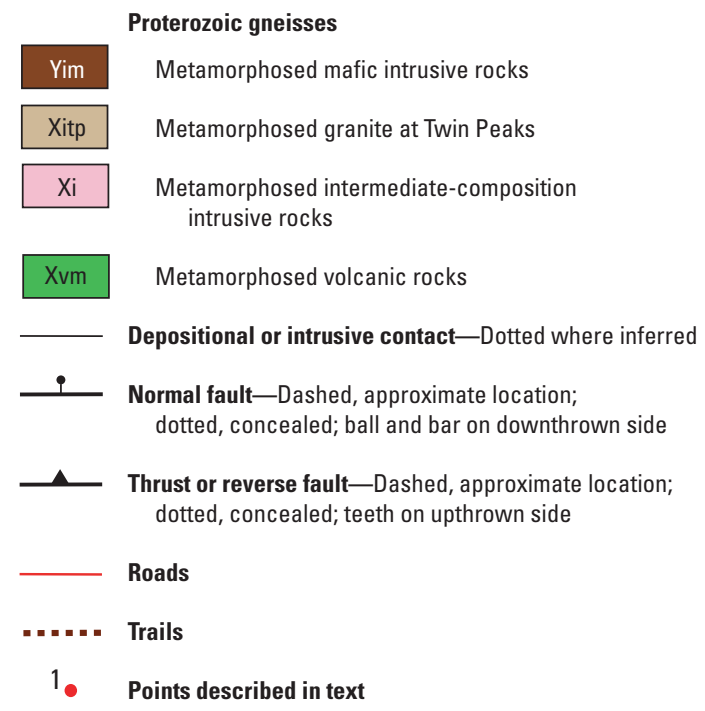

Figure 2. Geologic map of the region around the Mosca Pass Trail, compiled by Terry L. Klein, Ed DeWitt and Carma San Juan from mapping by Aughenbaugh (1958), Burford (1960), Bruce and Johnson (1991), Webster (2000), and D.A. Lindsey (unpub. mapping, 1985). 

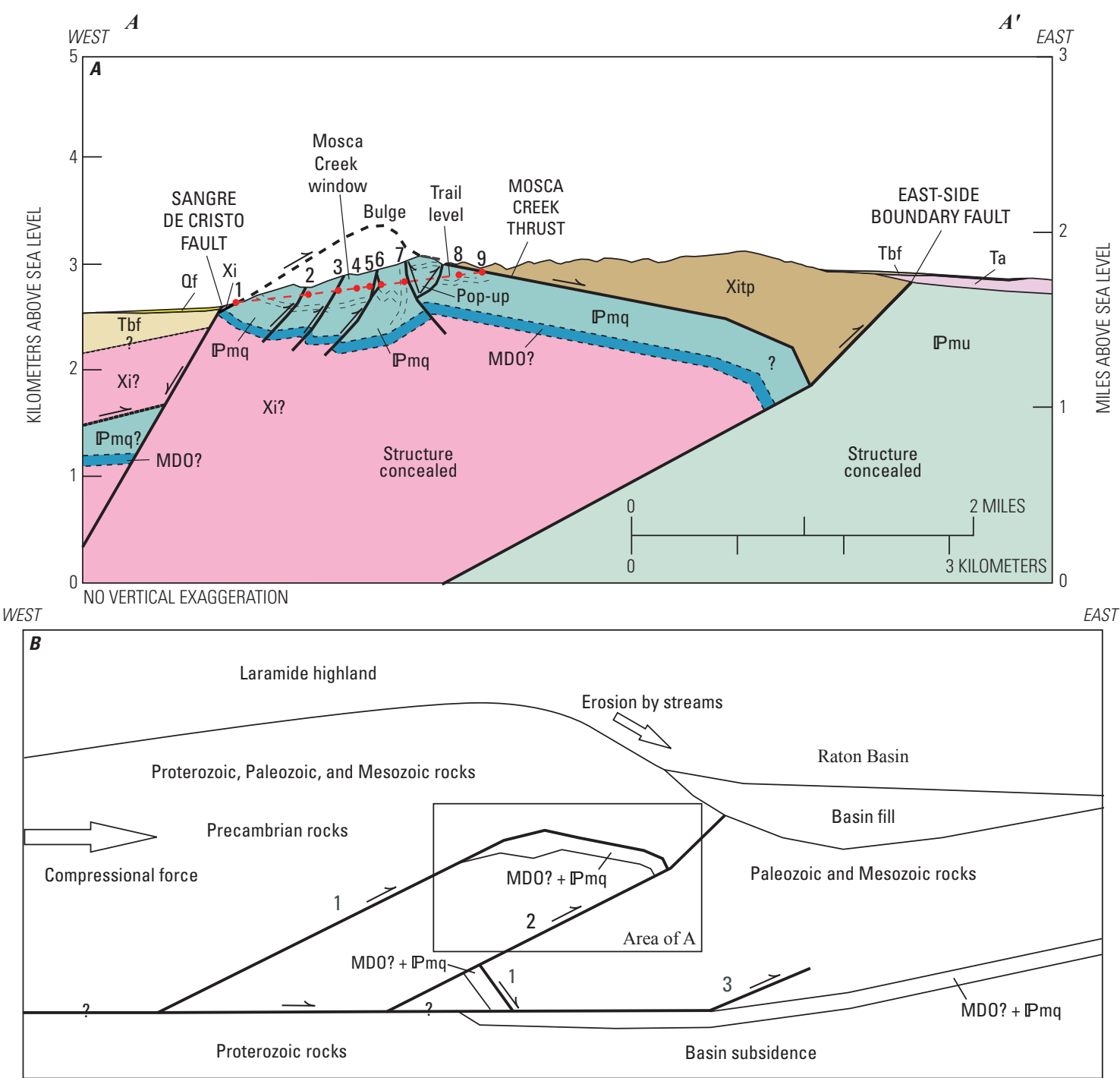

NO VERTICAL EXAGGERATION

EXPLANATION

Quaternary

Of Alluvial fan deposits

Tertiary

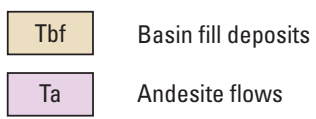

Pennsylvanian

Pmu Minturn Formation, undivided

Pmq Minturn Formation, lower part (quartz-pebble redbeds)

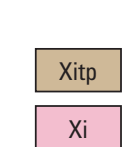

Proterozoic gneisses

Metamorphosed Twin Peaks granite

Metamorphosed intermediate-composition intrusive rocks

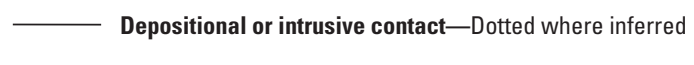

z zz:-z Bedding in sedimentary rock

_ Fault-Dashed, approximate location

$\rightleftharpoons \quad$ Arrows show sense of movement along faults

1. Points described in text

MDO Mississippian, Devonian, and

Ordovician sedimentary rocks

Figure 3. Geologic cross sections through the Sangre de Cristo Range at Mosca Pass. $(A)$ Cross section through the present-day range along the ridge side immediately north of the Mosca Pass Trail. (B) Cross section showing "the big picture" of thrusting that occurred in the early part of the Laramide orogeny 70-60 million years ago. Numbers beside faults in $3 B$ indicate interpreted order of fault movement: 1, Mosca Creek thrust; 2, east-side boundary fault; and 3, younger thrust breaking into Raton Basin. 


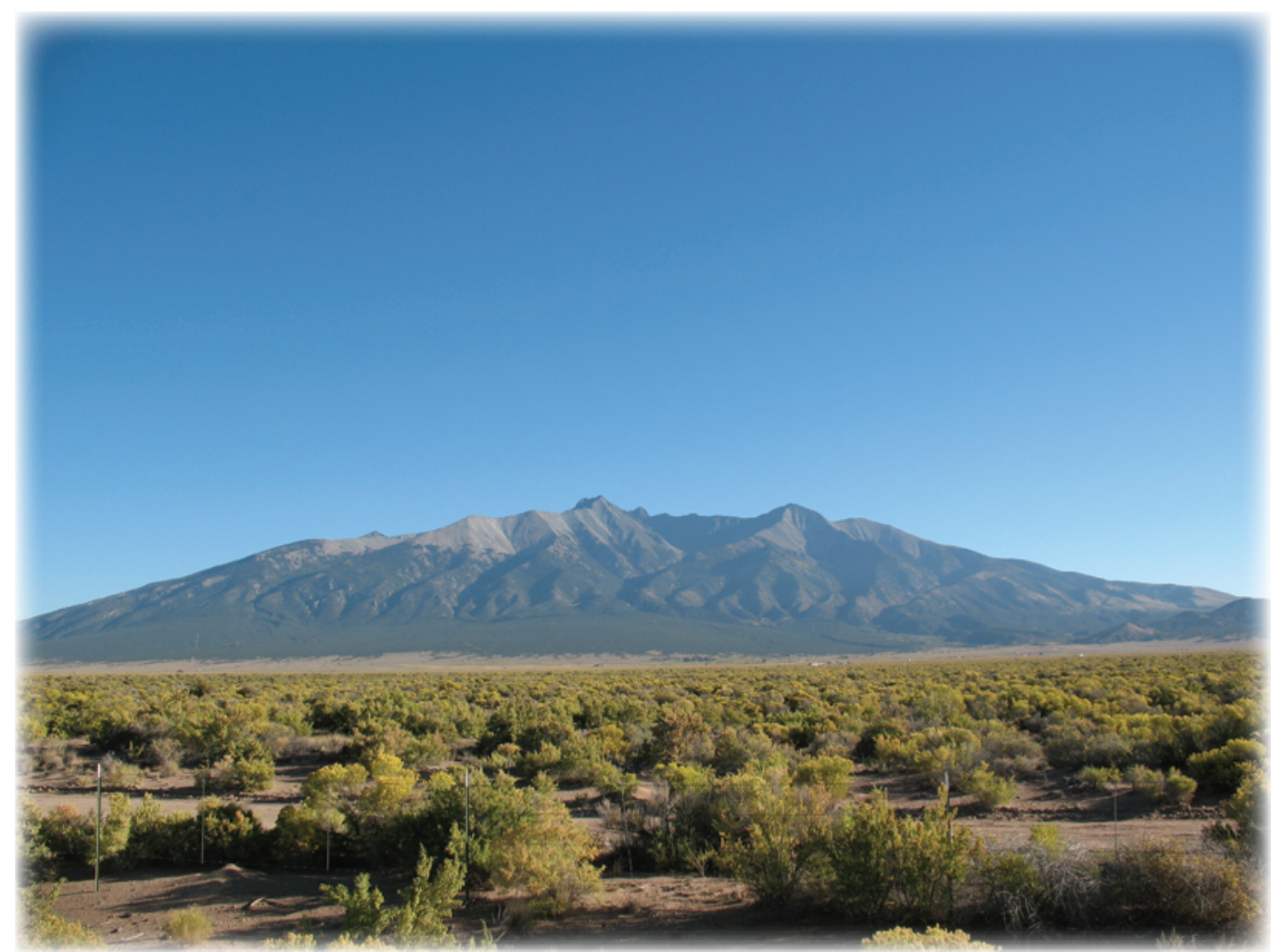

Figure 4. The young fault boundary on the southwest side of Sierra Blanca (see index map) is revealed by faceted spurs on the mountainside and scarp lines at the heads of alluvial fans. Photograph was taken from U.S. highway 160, 2 miles east of junction with Colorado highway 150 ( 5 miles south of the range front).

Figure 5. The old fault boundary on the east side of the Sangre de Cristo Range between Mosca Pass (left) and Medano Pass (right) has embayed valleys and rounded slopes. The distant grassy slopes are underlain by alluvial gravel shed from the range during uplift millions of years ago. The fault boundary is exposed as a Laramide age thrust south of Medano Pass but is concealed beneath pediment gravel (grassy slope) near Mosca Pass. Photograph was taken from Colorado highway 69, 2 miles east of Gardiner, Colorado (16 miles east of range front).

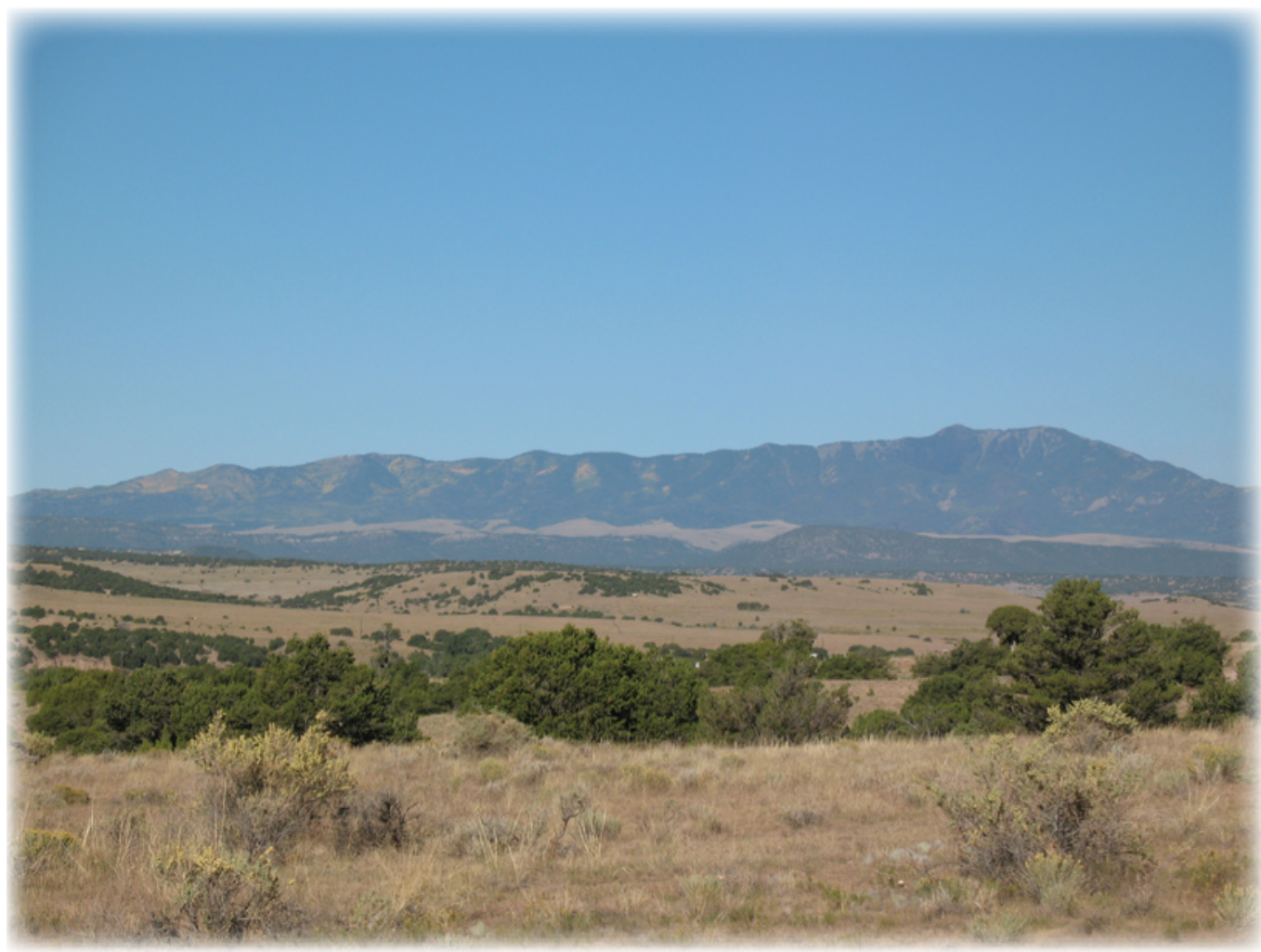


The Sangre de Cristo fault passes through the parking lot at the west end of the Mosca Pass Trail. The fault is marked by scarps in alluvium and bedrock. A good example of a scarp in alluvium extends north from the trees on the north side of the lot (best viewed from the paved road north of here). A bedrock-alluvium scarp is located immediately south of the parking lot. If you hike southeast from park headquarters past the water tank and up the trail to Morris Gulch, you will walk alongside another fault scarp in alluvium. These scarps in alluvium represent surface ruptures above the bedrock fault when the fault last moved, a few thousand years ago. Farther south, extensive scarps cut the alluvium around the foot of Sierra Blanca (the Spanish name for the mountains around Blanca Peak; see index map). The ridgelines extending from the mountains are truncated by faceted spurs (fig. 4). This side of the Sangre de Cristo Range is geologically young, formed by normal faulting during the last few million years.

Where streams emerge from the mountains, they deposit alluvial fans in response to decreasing channel slope. During the ice ages, streams swollen with glacial meltwater deposited large fans of coarse gravel hundreds of feet thick around the southwestern side of Sierra Blanca (fig. 4) (Peterson, 1971). Valleys of Sierra Blanca have the signature U-shaped cross section of valleys carved by glaciers. When the climate warmed after the last ice age, deposition stopped and streams began cutting canyons into the fans. In contrast to the valleys of the Sierra Blanca, the valleys around Mosca Pass (see index map) were never occupied by glaciers. The valley of Mosca Creek and those to the north have V-shaped cross sections carved by streams. Streams in these unglaciated valleys deposited small alluvial fans like the one beneath the trailhead parking lot. Such alluvial fans are much smaller than their iceage counterparts around Sierra Blanca.

The boundary fault east of Mosca Pass is concealed by younger rocks (figs. 2 and 3). Huerfano County road 583 ascends Mosca Pass from the east through the canyon of May Creek, a tributary of the Huerfano River. The canyon is cut through a thick sequence of sandstone belonging to the Minturn Formation of Pennsylvanian age. After leaving the canyon, the landscape opens onto grasslands composed of rounded ridgelines and valleys that slope gently away from the Sangre de Cristo Range (fig. 5). The surfaces of the grasslands are underlain by loose, coarse gravel visible in road cuts and a prominent borrow pit along the road. This gravel is composed almost entirely of gneiss eroded from the mountains to the west. At places the grassy surfaces underlain by gravel extend into the mountains giving the range front a slightly embayed appearance, although the overall impression of the front from a distance is linear. No fault scarps cut alluvium on the grasslands, and no truncated spurs mark the ends of ridgelines. As the road ascends into the range by switchbacks, it cuts through fractured gneiss, a metamorphic rock. No major fault is exposed in the gneiss.
The boundary fault east of Mosca Pass must be concealed under the gravel-mantled grasslands. Along Huerfano County road 583 only about 2 miles separate exposures of Proterozoic gneiss on the west from sandstone of Pennsylvanian age on the east. Just a few miles north of the road, the boundary fault is exposed. There, Proterozoic gneiss overlies sandstone of Pennsylvanian age along a fault that dips west beneath the range. To the north, the topographic front of the range is nearly coincident with the boundary fault, reflecting the contrast in erosional resistance between gneiss (more resistant) and sandstone. At the road and to the south, however, the mountain front has retreated west about 1 mile, indicating that the range front has been eroded for a long time. The presence of cemented gravel and volcanic rock beneath the gravel points to earlier episodes of erosion.

The gravel beneath grassy surfaces was eroded from the mountains by streams millions of years ago. As the Huerfano River excavated the topographic basin now called "Huerfano Park," it paused during times when erosion balanced deposition, leaving behind stable surfaces underlain by gravel. Where these surfaces flank streams in the park, they are called "terraces." In uplands drained by streams emerging from the mountain front, they are called "pediments." The streams flowing from the mountains today are the same ones that formed the pediments, but they have gradually cut into the pediments, so that today the pediments stand above stream level. Gravel deposits beneath the pediments are much thinner than the alluvial-fan deposits on the southwest side of Sierra Blanca. No meltwater rushed down the streams between Mosca Pass and Medano Pass, and no glaciers filled their valleys, probably because this part of the range was never high enough to support year-round accumulation of snow and ice.

\section{The Mosca Creek Window}

Between the Sangre de Cristo fault and the east-side boundary fault, erosion has exposed a structural window beneath another fault, called the "Mosca Creek thrust" (figs. 2 and $3 A$ ). This thrust is correlated with other thrusts south of Carbonate Mountain and at California Peak (see index map) and north of the head of Garden Creek. Its topographic and structural position high in the range indicates that it overlies the east-side boundary fault. The west side of the Mosca Creek thrust has been cut off by the Sangre de Cristo fault, confirming that the thrust was there first. Likewise, the east side of the Mosca Creek thrust is interpreted to have been cut by the east-side range-boundary fault, but that interpretation is less certain because the boundary fault is obscured by younger rocks. These relations only specify relative age; they do not distinguish between great gaps in time (such as between Laramide thrusting and Rio Grande rifting) and smaller gaps (such as the movement of individual Laramide age faults). 
The Mosca Creek thrust and overlying rocks rode on other rocks above the east-side boundary fault, bending and breaking as the latter advanced over the Raton Basin (fig. 3B). A younger thrust fault is shown breaking east in the footwall of Paleozoic and Mesozoic rocks, beneath the western side of the Raton Basin. Such thrusts can actually be observed at the surface in Huerfano Park. Possibly other thrusts overlay the Mosca Creek thrust; if so, they have been removed by erosion. The east-side boundary fault is shown as flattening west, beneath the Laramide highland, but whether the fault actually flattens to horizontal beneath the highland or continues down into deeper levels of the Earth's crust is unknown. Such uncertainties are indicated by question marks and notes on the cross sections.

Four Proterozoic gneiss units overlie the Mosca Creek thrust - three gneiss units about 1.7 billion years old (units $\mathrm{Xvm}, \mathrm{Xi}$, and Xitp) and one gneiss about 1.4 billion years old (unit Yim) (see descriptions of gneiss units in Explanation for figs. 2 and 3). The three 1.7-billion-year-old gneiss units consist of (1) dark gneiss (Xvm, metamorphosed volcanic rocks), found within mixed gneiss; (2) mixed light- and dark-layered gneiss (Xi, metamorphosed intermediate composition intrusive rocks); and (3) light-colored gneiss (Xitp, metamorphosed granite of Twin Peaks) around Mosca Pass. The 1.4-billion-year-old gneiss consists of small areas of dark (mafic) metamorphosed intrusive rocks within older gneiss.

The window exposes red sandstone, siltstone, and shale of the lower member of the Pennsylvanian Minturn Formation, which is about 300 million years old. In addition to its red color, the lower member contains distinctive quartz pebbles and granules that set it apart from the rest of the Minturn Formation. It is never more than about 1,000 feet thick, a key measurement used in constructing the cross section of figure $3 A$. The cross section (fig. $3 A$ ) also shows sedimentary rocks of early Paleozoic age and gneisses of Proterozoic age beneath the Minturn Formation. Nowhere are these rocks exposed in the window, but their presence is predicted by exposures elsewhere in the range. For example, a thrust fault south of Carbonate Mountain, thought to be an extension of the Mosca Creek thrust, overlies a thin layer of lower Paleozoic sedimentary rocks on gneiss.

The Minturn Formation in the window was deformed and metamorphosed by heat and pressure. Small faults and fractures traverse the Minturn, and in places beds have been tilted and folded. The original red sedimentary rock of the Minturn Formation has been recrystallized to form hard metamorphic rock with abundant white quartz and green chlorite concentrated in fractures, indicating temperatures reached several hundred degrees Celsius. Spectacular striated fracture surfaces called "slickensides" are everywhere. The thrust itself is marked by broken, angular fragments (breccia) of gneiss overlying red Minturn Formation. The thrust breccia is as much as 100 feet thick in some places.

Several large reverse faults cut through the window of Minturn Formation (Webster, 2000) (figs. 2 and 3). The reverse faults are visible along the trail and were spectacularly illustrated in a series of annotated photographs by R.J. Webster (2000) of the valley wall and ridge north of Mosca Creek.

Movement on most of the reverse faults was from west to east, but one fault moved rocks in the opposite direction. Together, these faults formed a bulge of deformed Minturn Formation beneath the thrust, accounting for the change in dip of the thrust from west to east. The thrust warped as the gneiss above it moved over bulges in the underlying Minturn Formation and later when the entire package of rocks moved on the east-side boundary fault. Thus, the resulting surface of the Mosca Creek thrust is very irregular; it rises from 8,300 feet at the trailhead to 11,200 feet at one point along the range crest south of Mosca Pass. The reverse faults below the thrust are interpreted as originating in Proterozoic rocks, but some faults may well have their origins in the Minturn Formation.

Rocks in the window are also cut by east-trending tear faults (Webster, 2000). All of the tear faults mapped in the window have small displacements. Tear faults are commonly vertical and strike across the trend of other structures; they reflect differences in the amount of horizontal movement or transport during thrusting. Tear faults also indicate the presence of another thrust below the window, evidence for the projection of the east-side boundary fault beneath the range (fig. 3). Tear faults in the window form zones of weak, easily erodible rock. Thus stream valleys may follow tear faults. One tear fault appears to follow Mosca Creek; it is not shown on figures 2 and 6 , because it follows the creek and the trail so closely that including it would obscure the trail shown in the figures. South of Mosca Creek, a prominent limestone bed with marine fossils has been offset by another tear fault. The tear fault on Mosca Creek may have weakened the rocks in the window, promoting downcutting and influencing the location of the creek channel.

Mosca Creek, as well as Morris Gulch to the south and Garden Creek to the north, have cut steep, narrow canyons most of the way through the range. Unlike the other canyons in the Sangre de Cristo Range, which become steep near their heads, the upper part of Mosca Creek flows through a broad meadow. The gradient of Mosca Creek changes from about $550 \mathrm{feet} / \mathrm{mile}$ in the sandstone window (first 2 miles) to about $300 \mathrm{feet} / \mathrm{mile}$ in the gneiss east of the window (last mile), suggesting that rock type has influenced stream gradient. Morris Gulch and Garden Creek, both entirely in gneiss, have steep gradients averaging about 1,000 feet/mile. Most canyon cutting happens during floods like the ones that washed out the wagon road in Mosca Creek in the early 1900s. Steep canyon walls provide abundant sediment to Mosca Creek by means of both gravity-driven sliding and slope wash.

Two trails, the Montville Nature Trail and the Mosca Pass Trail, leave from the parking lot at the mouth of Mosca Creek, 0.25 mile northeast of the Park Visitor Center. We recommend that you walk the Nature Trail first, stopping at point 1, where you can see gneiss and fault breccia, the Mosca Creek thrust fault, a dike, slickensides, and red sandstone of the Minturn Formation-all in one place. 


\section{The Trail Guide}

\section{Locating Yourself on the Trail}

You can use the topographic map (fig. 6) to locate approximately each point of interest. In our descriptions we provide some approximate distances between points and reference a prominent notch cut in rock along the trail about 0.5 mile east of the point where the Mosca Pass Trail leaves the Montville Nature Trail. If you have a global positioning system (GPS) unit, use the coordinates given in the captions for figures 7 to 15 to locate each point of interest along the trail. These coordinates are formatted in degrees and decimals using the 1983 North American Datum (NAD83). NAD83 coordinates should also be close to those of the 1984 World Geodetic System (WGS84), which is the default datum for most GPS units and is used by Google Earth, so you can probably leave your unit set on the default. Comparisons with locations in Google Earth indicate that the coordinates should be accurate within 50 feet and, in most cases, 10-20 feet. Be aware that paper versions of the 1:24,000-scale U.S. Geological Survey (USGS) topographic maps of Mosca Pass (published in 1967) and Zapata Ranch (published in 1965) are based on an older standard, the 1927 North American Datum, which may not agree well with coordinates in a newer datum. If your GPS provides elevations, they can also serve as a general guide to confirm your location. Comparison of GPS elevations indicate that they should be within one contour interval ( 40 feet) of the elevation indicated on the topographic map (fig. 6). Finally, photographs of the trail help to locate most of the points.

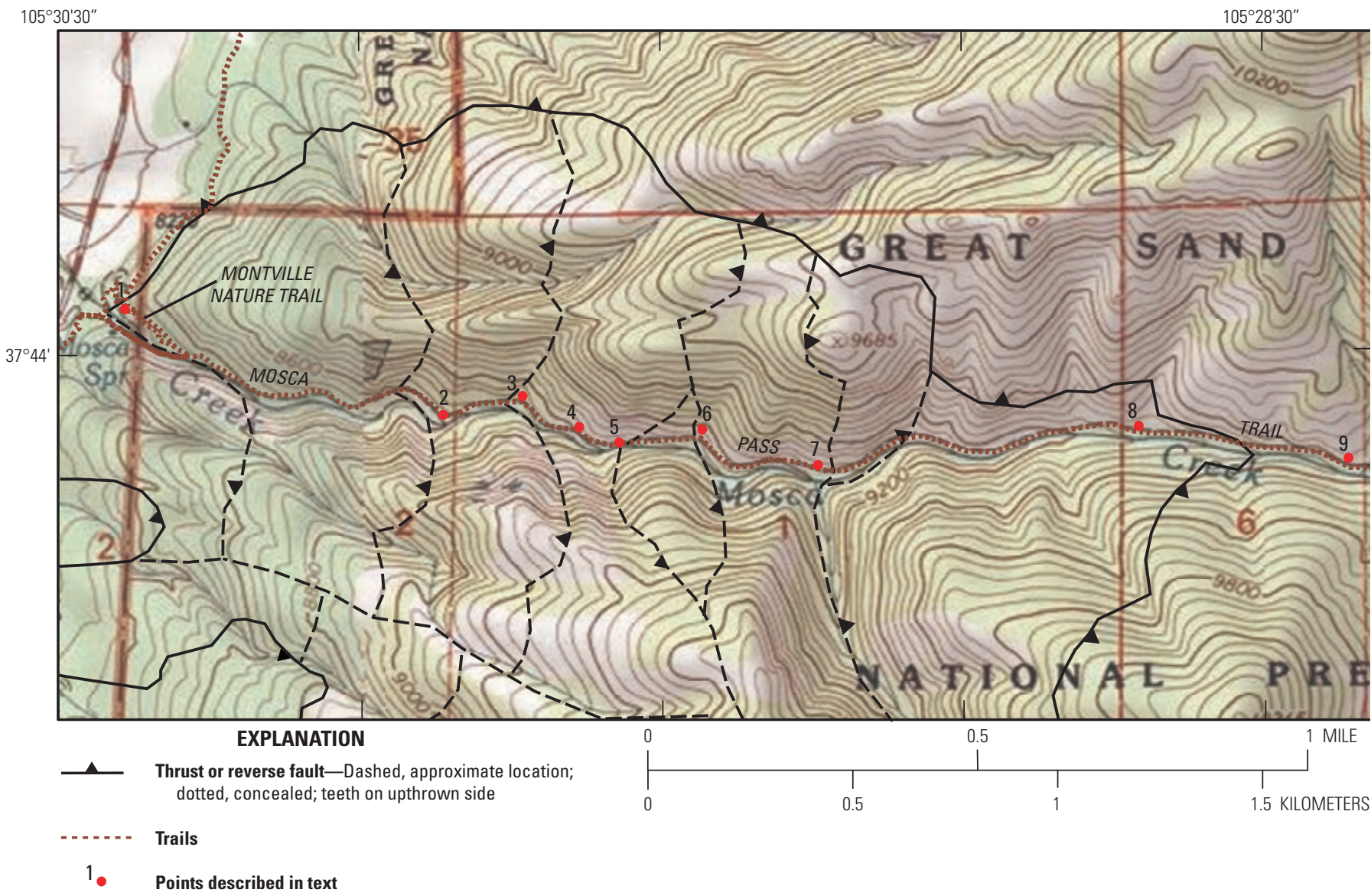

Figure 6. Topographic map showing location of points of geologic interest along the Montville Nature Trail and the Mosca Pass Trail. Faults shown on figure 2 are shown here for reference. Contour interval is 40 feet. 


\section{Rocks Along Montville Nature Trail}

POINT 1: The short self-guided Montville Nature Trail follows a loop north of the entrance to the Mosca Pass Trail. From the Mosca Pass trailhead parking lot east of the Visitor Center, enter the trail through a grove of cottonwood and aspen trees and take the Montville Nature Trail immediately to your left. Cross Mosca Creek, and walk uphill through switchbacks cut in gravelly soil of decomposed gneiss. As you reach the summit of the loop, you will come to a large lightcolored outcrop that forms a small point on the ridgeline (point 1 , figs. 6 and $7 A$ ). This outcrop is an igneous dike formed when molten magma intruded the Mosca Creek thrust about 30 million years ago. The dike extends up the ridge, crossing an old irrigation ditch and the trail leading north to the campground. Immediately west of the dike on the nature trail, brown rock composed of gneiss fragments is thrust breccia. Immediately east of the dike are tilted beds of red sandstone and shale of the Minturn Formation (fig. 7B). You are entering the window beneath the thrust.

\section{A}

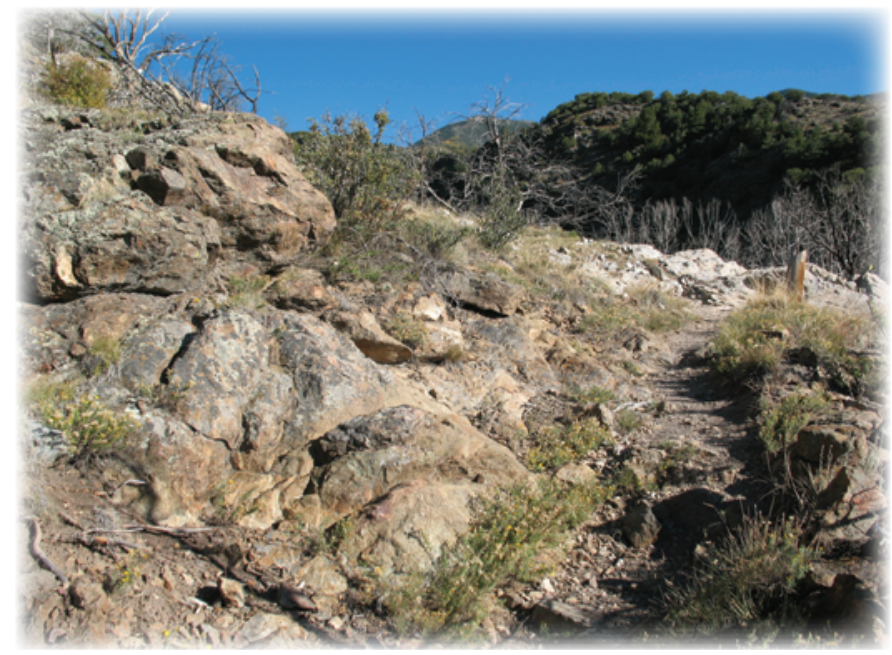

B

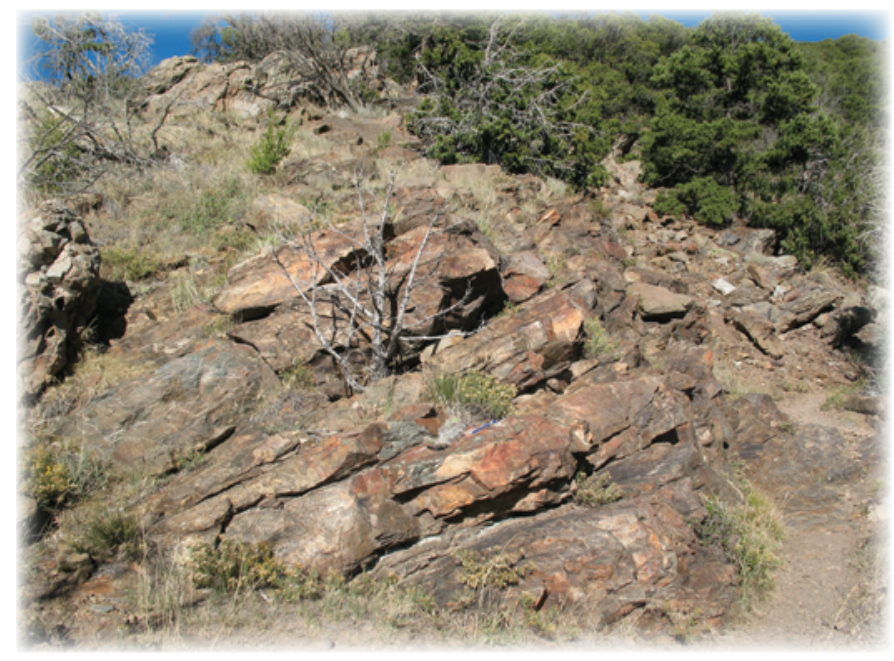

Before proceeding east beyond the dike, take a look at the nearly vertical, northwest-trending fractures in the dike. The fractures have brown, striated surfaces called "slickensides" (fig. 7C). The striae (technically, these are called "slickenlines") mark the direction of movement along surfaces. Slickensides commonly display small curved fractures called Reidel shears that reveal the sense of movement (Petit, 1987). Slickenside striae in the dike are steeply inclined and show down-to-the-west movement, like the fault scarp in alluvium north of the parking lot. These slickensides were formed during Rio Grande rifting and are younger than the gently dipping slickensides exposed along the trail in gneiss west of the dike and in sandstone east of the dike. The gently dipping slickensides probably formed during the Laramide orogeny.

Slickensides in sandstone of the Mosca Creek window have been studied several times with conflicting interpretations. In the most recent study, Webster (2000) concluded that most of the slickensides were formed during the Laramide orogeny, and that the striae show movement along a line 70 degrees east of north. That direction is typical of Laramide fault movement in this part of Colorado and is consistent with the slickensides in gneiss and sandstone along the trail near point 1 .

Follow the nature trail east, down to the bridge that crosses Mosca Creek. On the south side of the creek, take a look at the boulder with a plaque on it; the green striated surfaces on the boulder are slickensides. Now cross back to the north side of the creek and proceed east up the Mosca Pass Trail.

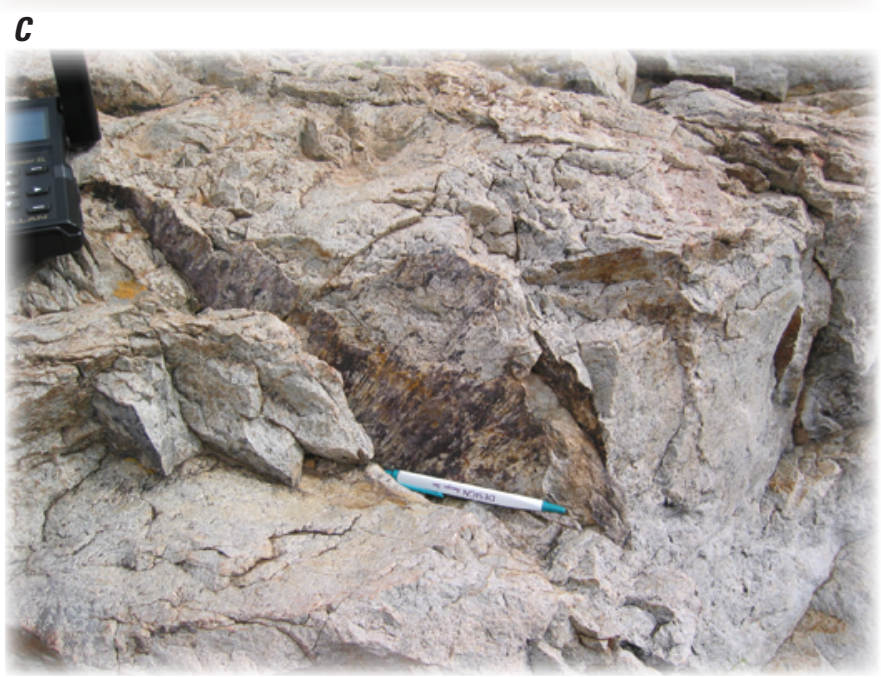

Figure 7. Photographs at point 1, Montville Nature Trail (lat $37.73443^{\circ} \mathrm{N}$. , long $105.50714^{\circ} \mathrm{W}$., elev. 8,320 feet): $A$, Looking southeast up the trail at a light-colored igneous dike. Brown rock in foreground is thrust breccia gneiss; valley of Mosca Creek in background. $B$, Looking east from igneous dike at red sandstone of the Minturn Formation in the Mosca Creek window. C, Slickensides (above pen) in light-colored igneous dike showing down-to-west movement of Rio Grande rift faulting. Pen approximately 6 inches long shows scale. 


\section{Rocks Along Mosca Pass Trail}

POINT 2: As you walk up the trail through red rocks of the Minturn Formation, about 0.4 mile east of the plaque at the trail entrance, you will encounter numerous examples of slickensides in both outcrops and loose blocks (point 2, figs. 6 and $8 A$ ). Many of these examples show Reidel shears (fig. $8 B$ ). Slickensides in the Mosca Creek window are nearly always composed of green chlorite and white quartz.

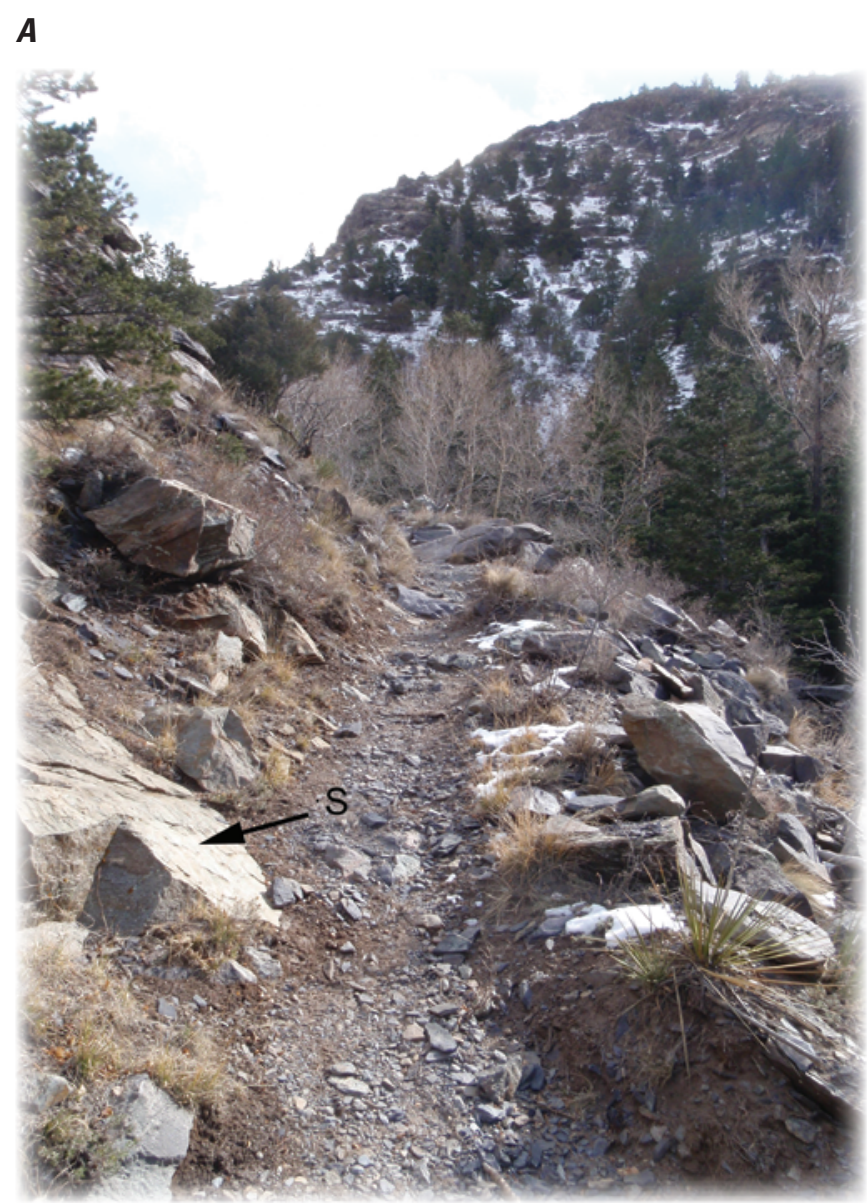

Figure 8. Photographs at point 2 (lat $37.73200^{\circ} \mathrm{N}$., long $105.49837^{\circ} \mathrm{W}$., elev. 8,610 feet): $A$, Looking east along the trail: slickensides, left foreground (S). $B$, Slickensides of greenish chlorite and white quartz on this sandstone block record fault movement in the Mosca Creek window during Laramide thrusting. Slickensides are composed of surfaces called Reidel shears that are inclined to the actual plane of movement. Photograph located in $C$. Blue pen approximately 6 inches long shows scale. $C$, Looking west at sandstone cliffs below skyline. Blocks with slickensides (S and $8 \mathrm{~B}$ ) along trail. A reverse fault runs down the gulch behind the spruce tree in center of photograph.
Just west of point 2, a prominent gulch at the foot of cliffs on the north side of the trail (fig. 8C) marks the westernmost of five reverse faults mapped in the Minturn Formation (see cross section, fig. $3 A$, unit Pmq). Rocks on the west side of the fault moved up and east. Although small parallel faults are exposed in the cliffs west of the fault, the cliffs are composed of erosion-resistant sandstone, in contrast to easily eroded crushed rock near the fault. Such cliff-and-gulch topography results from variable resistance of rocks to erosion along fault zones.

B

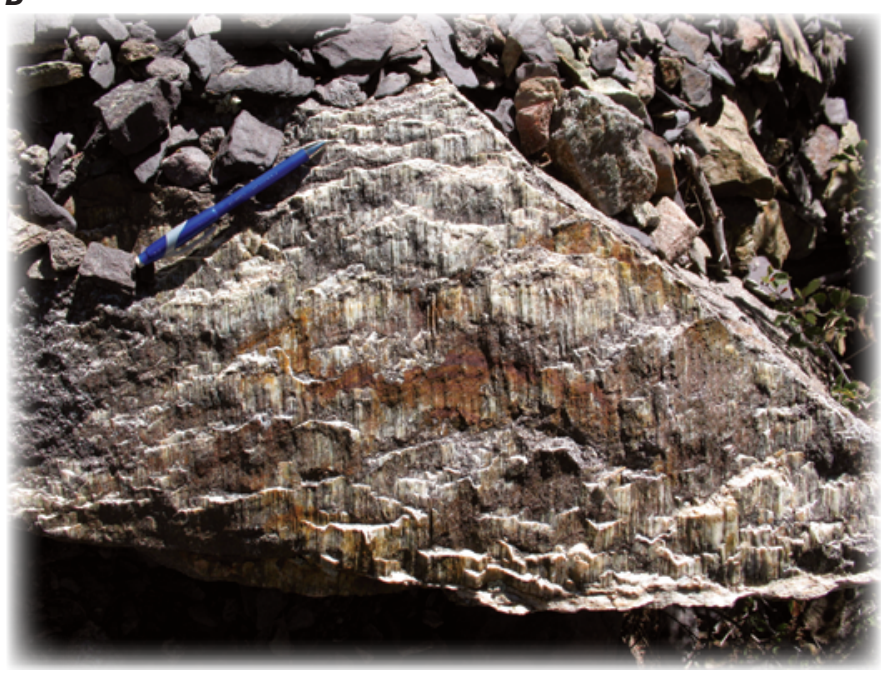

C

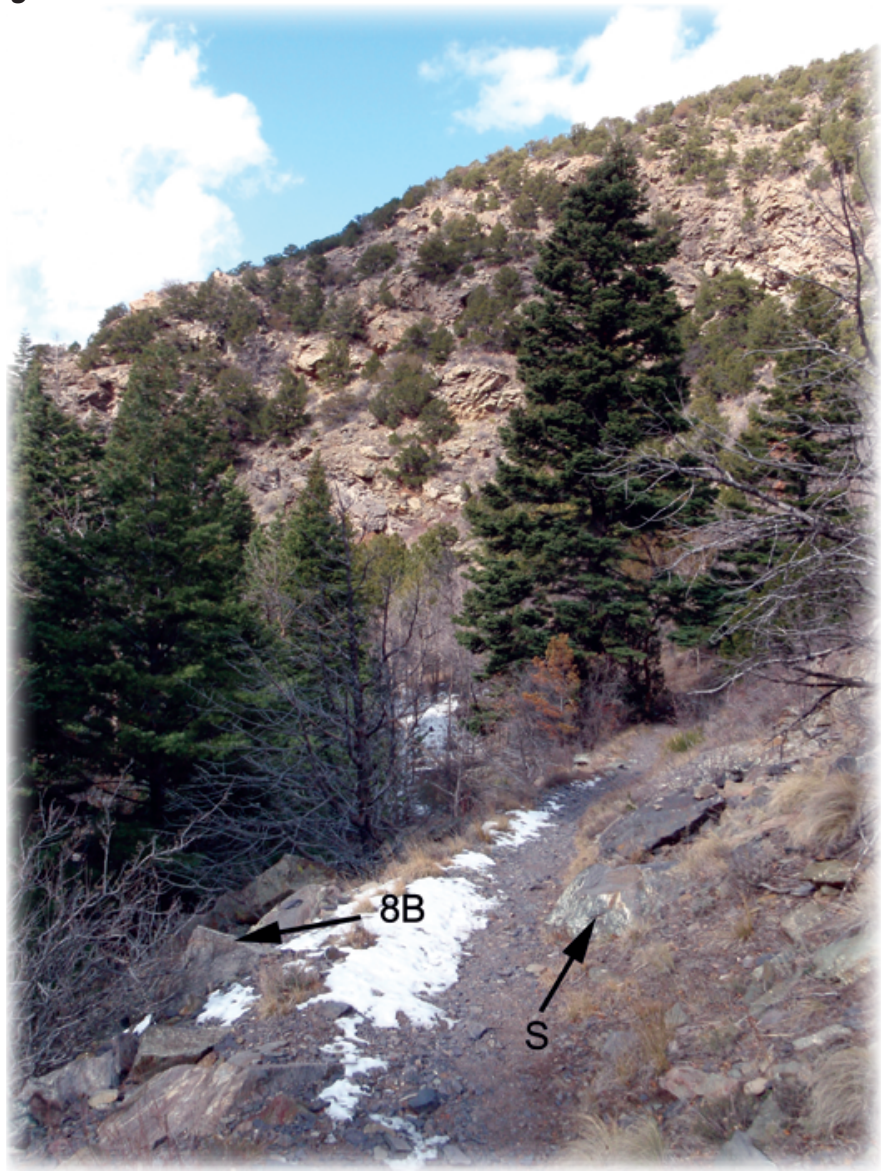


POINT 3: The trail passes by the wooden sign labeled "Sangre de Cristo Wilderness" and up through a prominent notch cut through rock (point 3, figs. 6 and 9A), located about 600 feet farther up the trail from point 2 . About 75 feet east of the notch is a broad anticline (upfold), defined by a single sandstone bed (fig. 9B). The bed represents the channel of an ancient stream during Pennsylvanian time; the shale above the sandstone bed represents overbank sediment deposited on an ancient floodplain as the channel meandered across it. The anticline was formed by compression and buckling of beds as the Mosca Creek thrust moved across the area during the Laramide orogeny. Small faults cut off the upfolded sandstone bed on both sides. On the west side of the anticline, two small faults are indicated by sheared rock along the trail about 50 feet east of the notch. Where the trail descends into a small gully about 140 feet east of the notch, another small fault cuts the anticline (fig. 9C). Slickensides on the fault show that the east side has moved up and over the anticline. Faults like these form on the sides of folds where beds have been crowded together; commonly, they bend and disappear into shale beds. These faults are in the footwall of the second reverse fault (counting from the west in the cross section of figure $3 \mathrm{~A}$. The second reverse fault crosses the trail about 250 feet west of the notch near the wilderness sign but is concealed by talus and vegetation.
$\boldsymbol{A}$

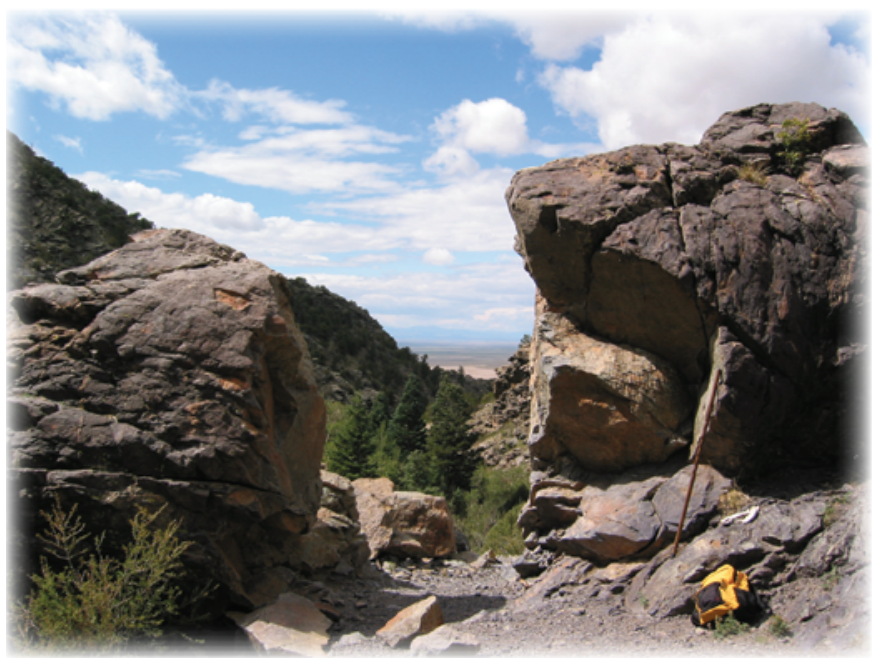

B

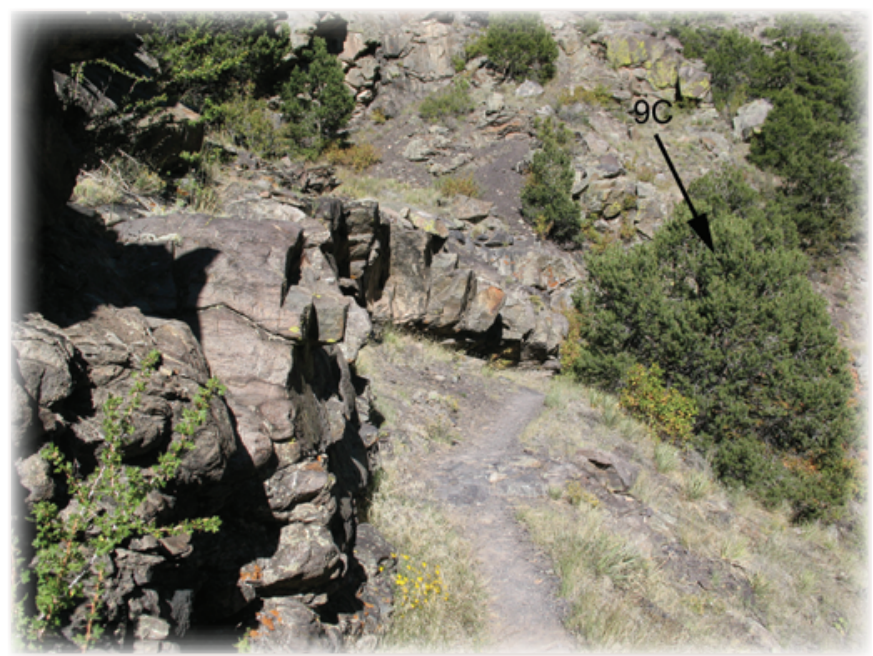

C

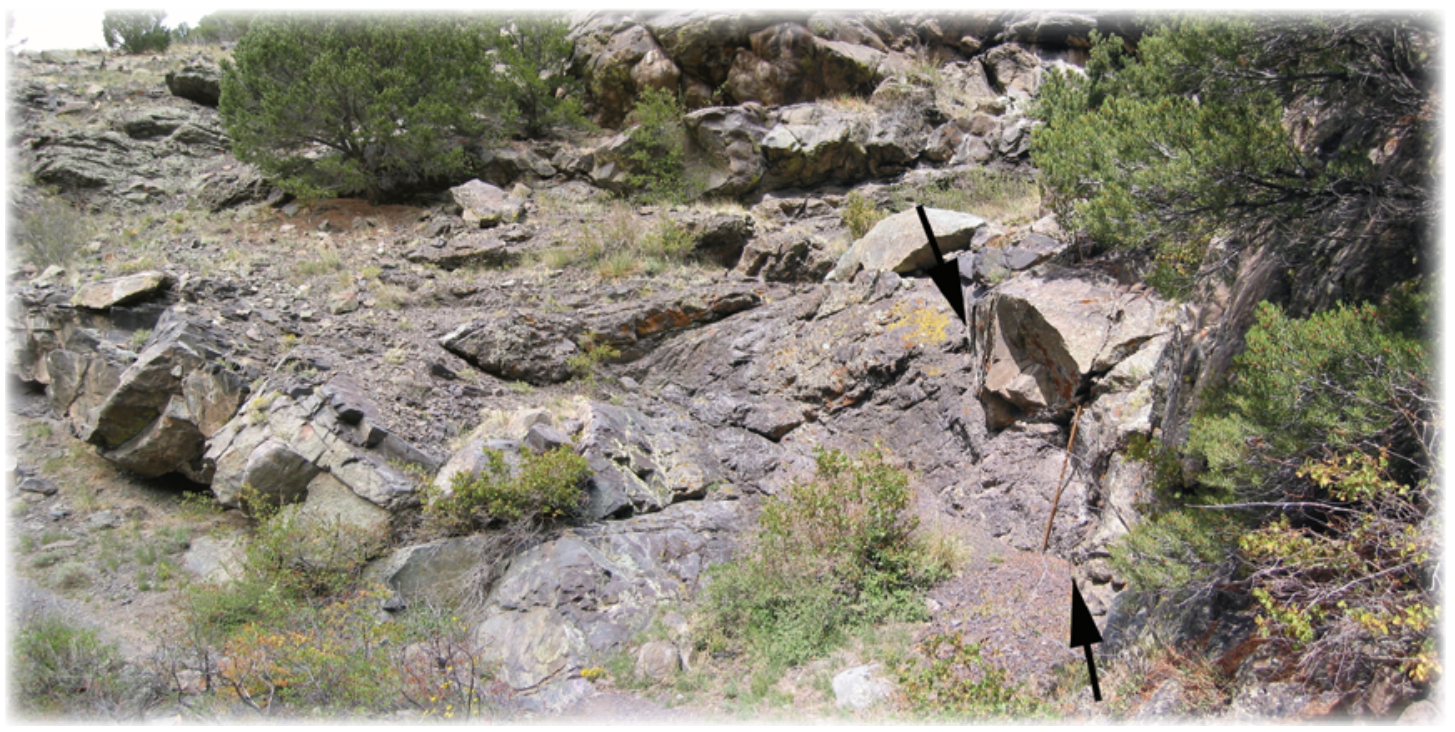

Figure 9. Photographs at point 3 (lat $37.73245^{\circ}$ N., long $105.49616^{\circ} \mathrm{W}$., elev. 8,730 feet): $A$, Looking west at trail in notch cut through sandstone. $B$, Broad fold in sandstone bed of Minturn Formation along the trail 75 feet east of notch. The fold was formed during the Laramide orogeny. The bed is about 5 feet thick. A small fault with slickensides is exposed above the trail, behind tree. $C$, Looking up at the small fault (between arrows) with slickensides (beside top of walking stick), east side of anticline. Photograph located in $B$, behind tree. $\ln A$ and $C$, walking stick is approximately 5 feet long showing scale. 
POINT 4: About 650 feet east of the anticline, you can find good examples of many sedimentary and structural features (point 4, figs. 6 and 10A). Slickenside surfaces and close-spaced fractures of varying orientation abound. Nearly horizontal slickensides display striae that are parallel to the direction of Laramide compression (fig. 10B); other, steeply inclined slickensides with striae of varying orientations record other components of strain. Beds of white quartz granules and red sandstone reveal the gentle dip here (fig. 10C). In the Sangre de Cristo Range, granules and pebbles of white quartz in red sandstone are diagnostic of the lower member

\section{$\boldsymbol{A}$}

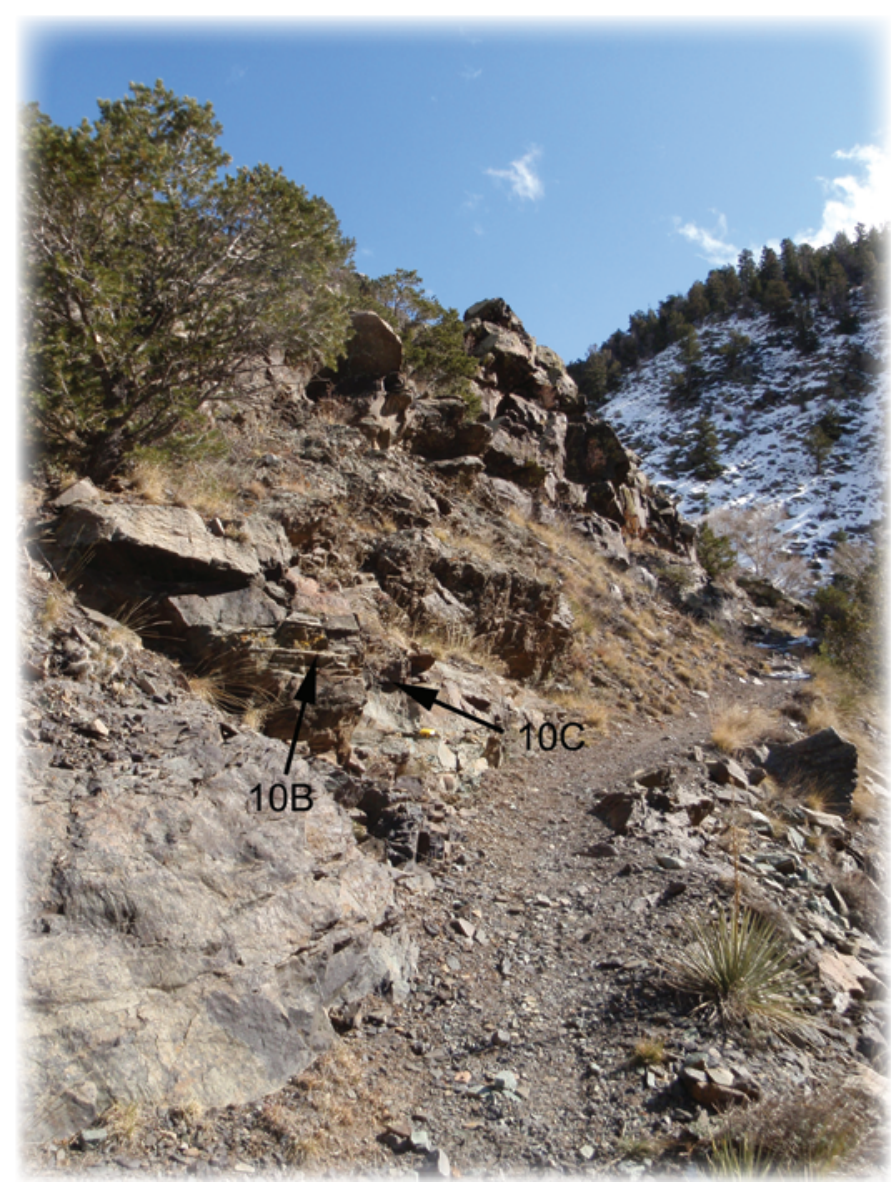

of the Minturn Formation. Quartz is one of the most resistant minerals to weathering and erosion. These quartz granules survived a long period of weathering over 300 million years ago, after which they were deposited by streams in the lower member of the Minturn Formation.

Red sandstone containing quartz granules and pebbles has been found beneath thrust faults at other localities north and south of Mosca Creek (Rhodes, 1964). This relation suggests that the Mosca Creek thrust underlies a very large area, from south of California Peak to a point several miles north of the head of Garden Creek.
B

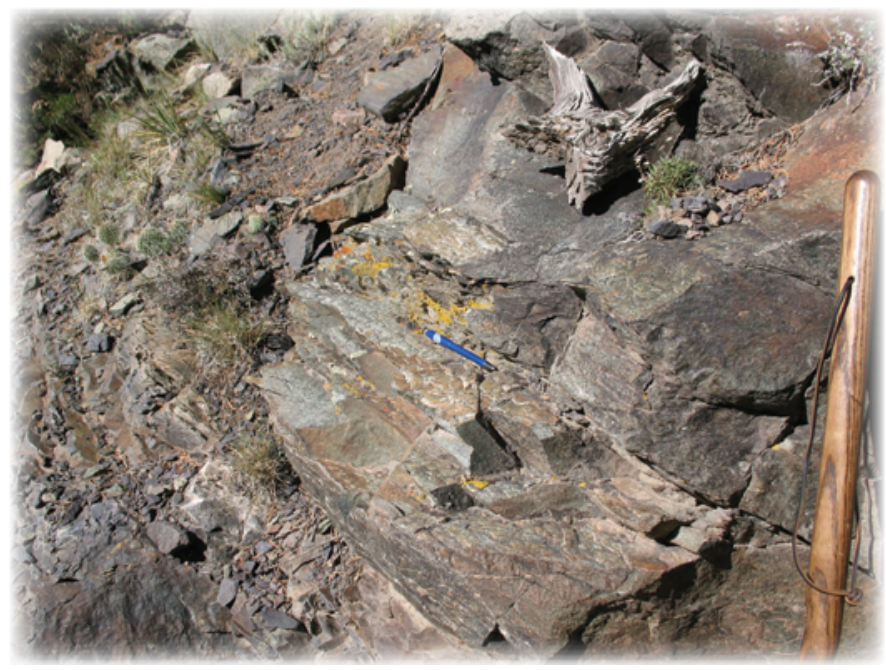

$\boldsymbol{C}$

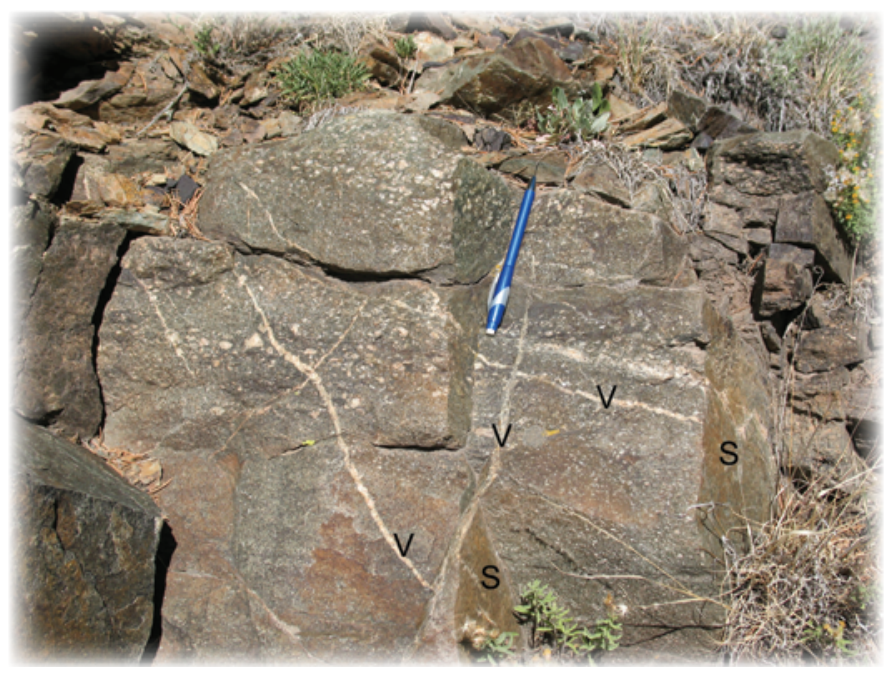

Figure 10. Photographs at point 4 (lat $37.73155^{\circ}$ N., long $105.49443^{\circ} \mathrm{W}$. , elev. 8,820 feet): $A$, Looking east along the trail. $B$, Nearhorizontal slickensides showing movement parallel to the compression direction of the Laramide orogeny. Note closely spaced striated surfaces of green chlorite and white quartz near blue pen; these are Reidel shears. Photograph is located at arrow in $A$. Blue pen is perpendicular to striae. $C$, Sandstone beds with white quartz granules are characteristic of the lower member of the Minturn Formation. Orientation of beds is approximately horizontal. Inclined veins (V) of white quartz and near-vertical slickensides (S) of green chlorite cut across beds. Veins are located at arrow in $A$. Blue pen approximately 6 inches long shows scale. 
POINT 5: The trail crosses fault breccia about 600 feet east of point 4 (point 5, figs. 6 and 11). Fractures with prominent light-brown altered margins separate blocks of red sandstone and shale. Altered margins probably formed by oxidizing waters that either ascended during hydrothermal activity or descended from the surface. The original bedded structure of the rocks is visible in individual breccia blocks; the orientation of bedding in the individual blocks is highly variable. Fault breccia is exposed for about 120 feet along the trail. The breccia marks the west strand of an east-directed fault and the western boundary of highly deformed Minturn Formation in the bulge shown on the cross section of fig. $3 \mathrm{~A}$. Loose blocks of rock and soil on steep slopes south of Mosca Creek indicate the probable continuation of the fault.

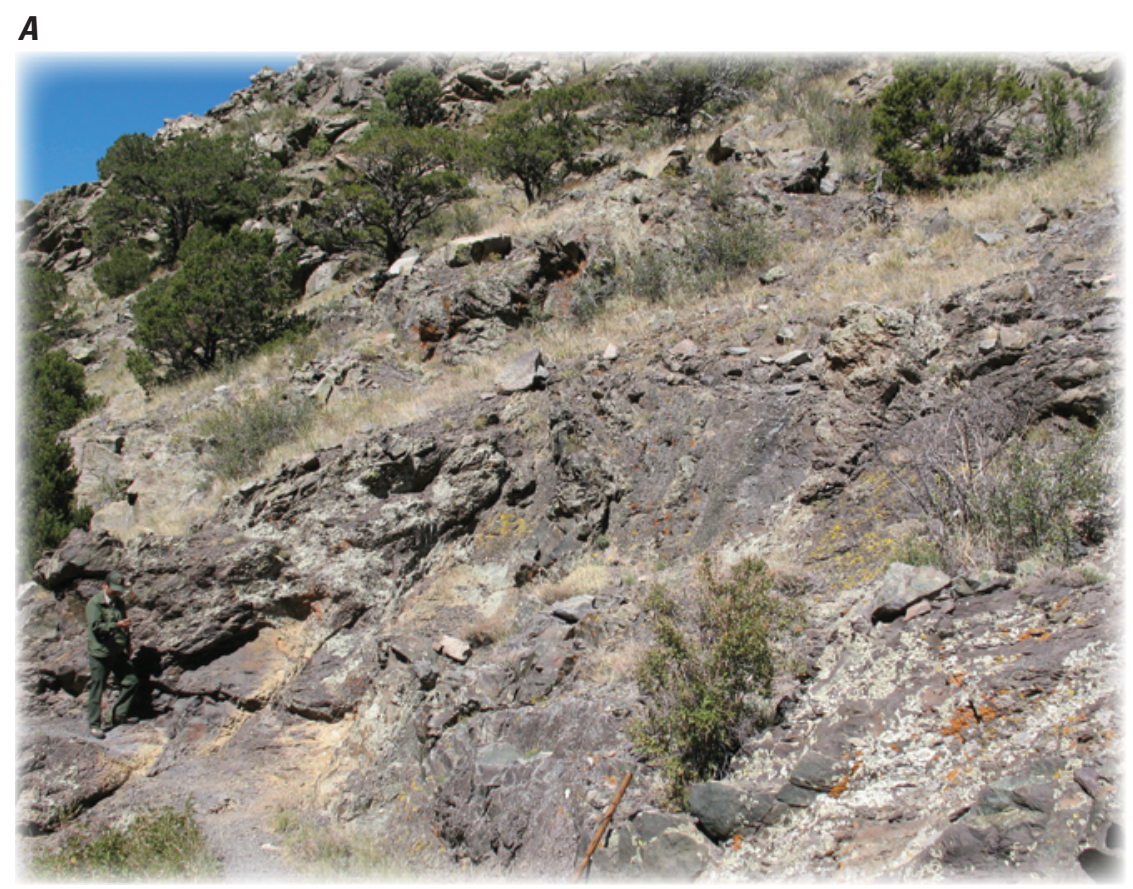

B

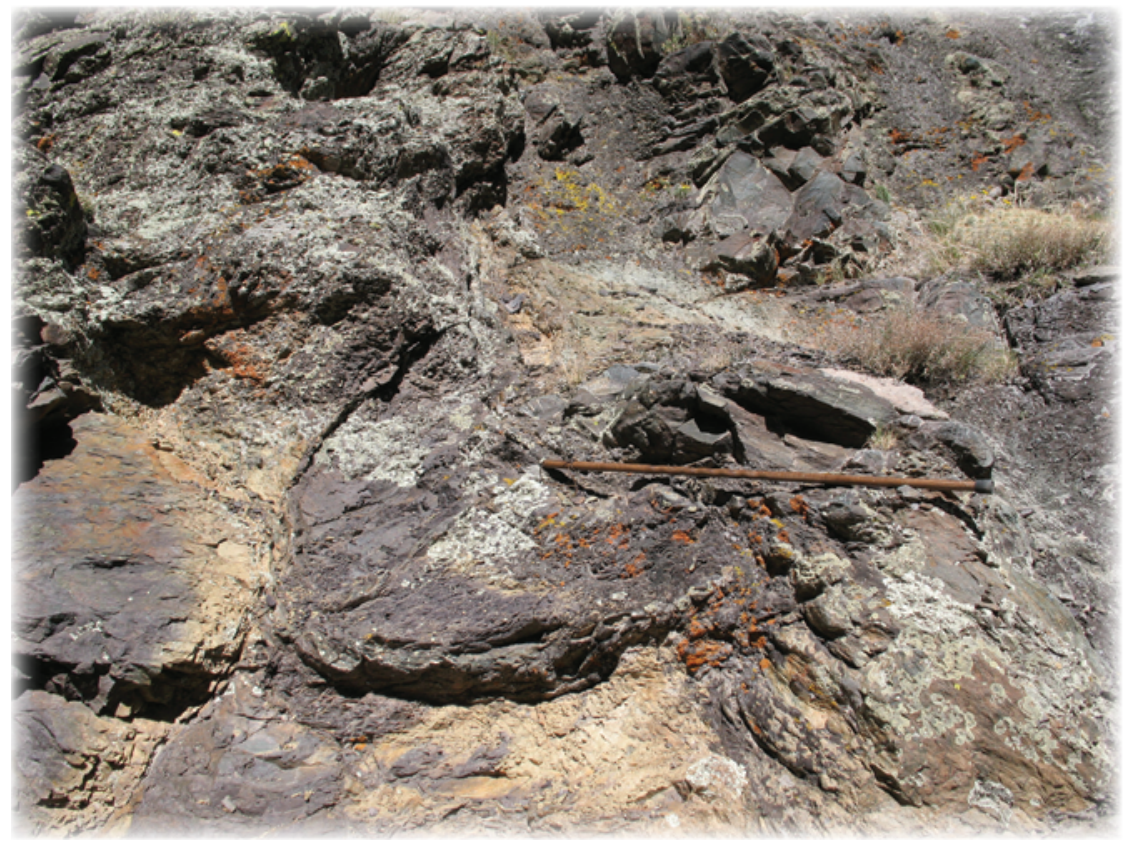

Figure 11. Photographs at point 5 (lat $37.73160^{\circ}$ N., long $105.49261^{\circ} \mathrm{W}$., elev. 8,860 feet): $A$, Looking west along trail at fault breccia with rotated blocks and altered zones along fractures. $B$, Close-up showing light-brown altered fracture margins and rotated blocks in fault breccia. Walking stick approximately 5 feet long shows scale. 
POINT 6: About 700 feet farther up the trail from point 5 , look up at a cliff overhanging a prominent fracture (point 6 , figs. 6 and 12A). The fracture is a strand of an east-directed reverse fault (located on fig. 6). Closely spaced fractures filled with quartz attest to the high degree of deformation of the sandstone in the footwall of the fault (fig. 12B). These fracture fillings are themselves sheared and folded revealing

\section{$\boldsymbol{A}$}

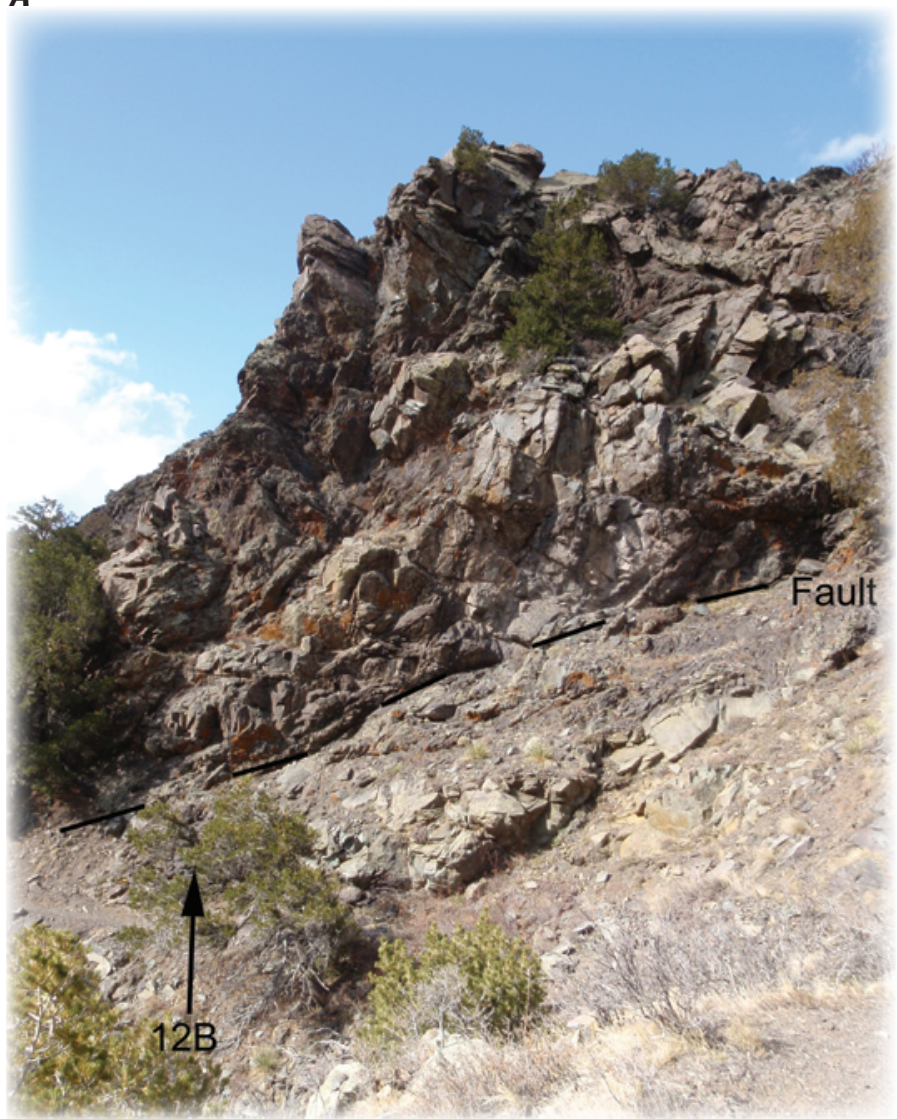

a complicated history of deformation as the overlying fault moved. The original sedimentary layers within these beds have been completely obliterated, yet bedding surfaces remain sufficiently intact to determine that they dip about 20 degrees north. Rocks in the bulge of faulted Minturn Formation between points 5 and 7 were compressed between two faults that moved in opposite directions.
Figure 12. Photographs at point 6 (lat $37.73165^{\circ} \mathrm{N}$., long $105.49118^{\circ}$ W., elev. 8,990 feet): $A$, Looking west at east strand of reverse fault (dashed) at point 6 (see fig. 6); fault is marked by a prominent left-dipping fracture in rock below the cliff. $B$, Deformation in footwall of fault along trail: closely spaced fractures filled with quartz (arrows point to examples) cut across red siltstone beds, located behind bush in $A$. Bedding trends from upper left to the middle right side of picture and dips about 20 degrees away from the observer. Pick approximately 12 inches long shows scale.

\section{B}

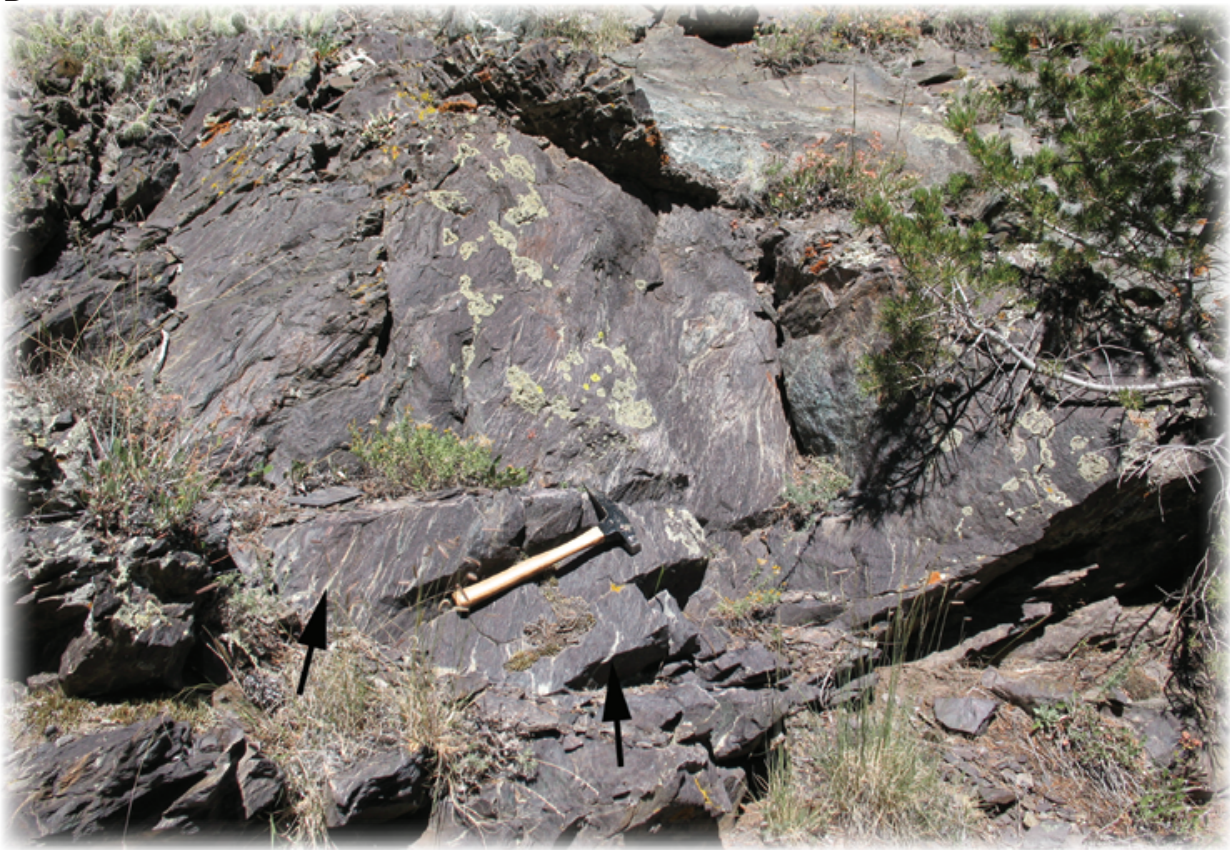


POINT 7: Steeply dipping sandstone beds of the Minturn Formation are exposed along the trail at point 7 , located about $900 \mathrm{ft}$ east of point 6 (figs. 6 and 13). Steeply inclined slickensides parallel to bedding indicate east-side-up movement. An exposure in the trees about 200 feet to the east reveals beds dipping about 70 degrees west, and 300 feet farther east beds dip gently north about 10 degrees. A westdirected reverse fault separates steeply dipping beds on the west from gently dipping beds on the east (see location of fault at point 7 on fig. 6). The steeply dipping beds were upturned by the west-directed fault. This is the eastern boundary of the bulge in the Minturn Formation below the Mosca Creek thrust fault.

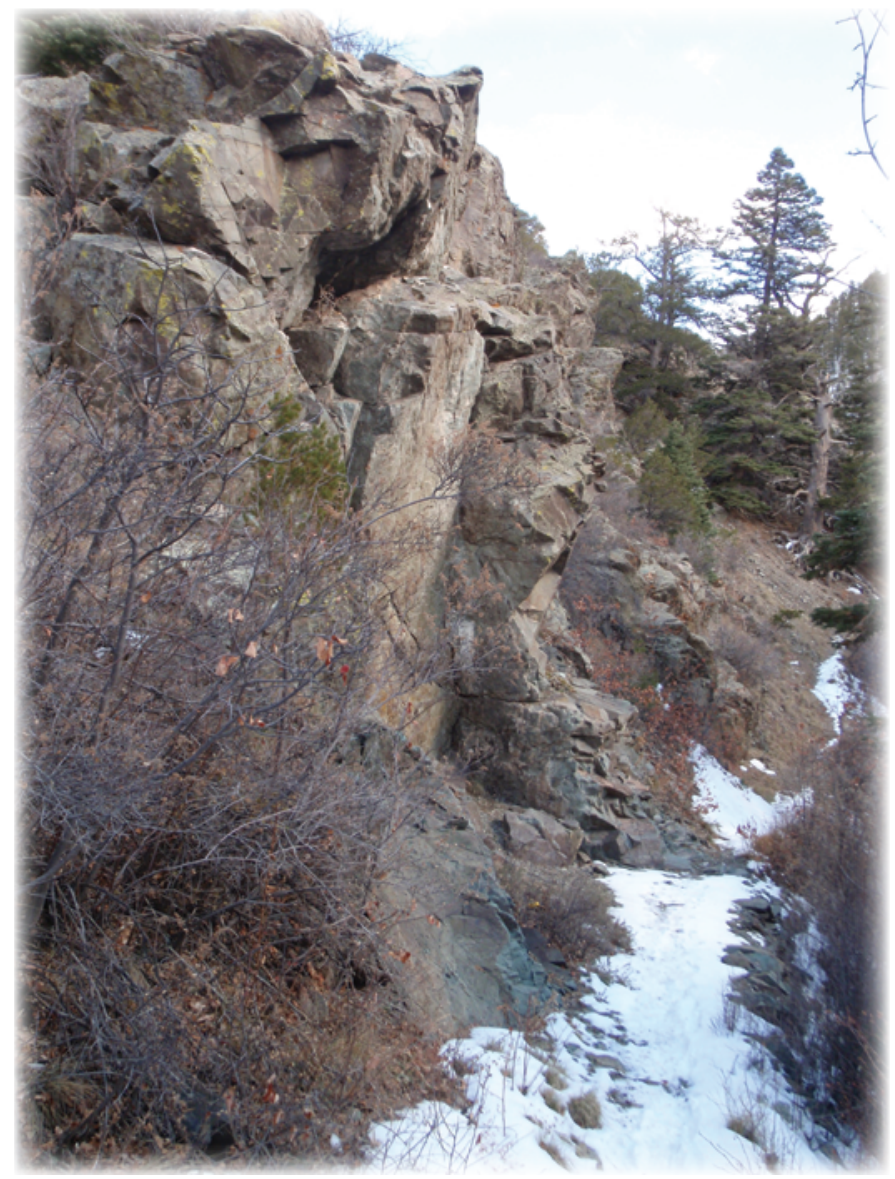

Figure 13. Photograph at point 7 (lat $37.73087^{\circ} \mathrm{N}$. , long $105.48865^{\circ} \mathrm{W}$., elev. 9,020 feet), looking east along trail at exposures of steeply dipping sandstone beds. Beds strike across the trail and dip steeply to the west, toward the observer. Additional exposures along trail are located in the trees. A west-directed reverse fault lies beyond the trees in the background.
POINT 8: The trail crosses a small alluvial fan about 0.55 mile east of point 7 , where a gully enters Mosca Creek from the north. This is point 8 (fig. 6) on the trail. Walk north of the trail about 100 feet into a clearing on the fan and look across the gully at a contact between reddish-brown rocks below light-brown rocks on the hillside (fig. 14). The contact is the Mosca Creek thrust fault. The reddish-brown rocks below the thrust contact are gently dipping beds of sandstone in the Minturn Formation. The light-brown rocks above the contact are brecciated gneiss. The thrust contact is easily located within a few feet between bedrock exposures; however, typically you cannot touch the contact because it is covered by soil and talus.

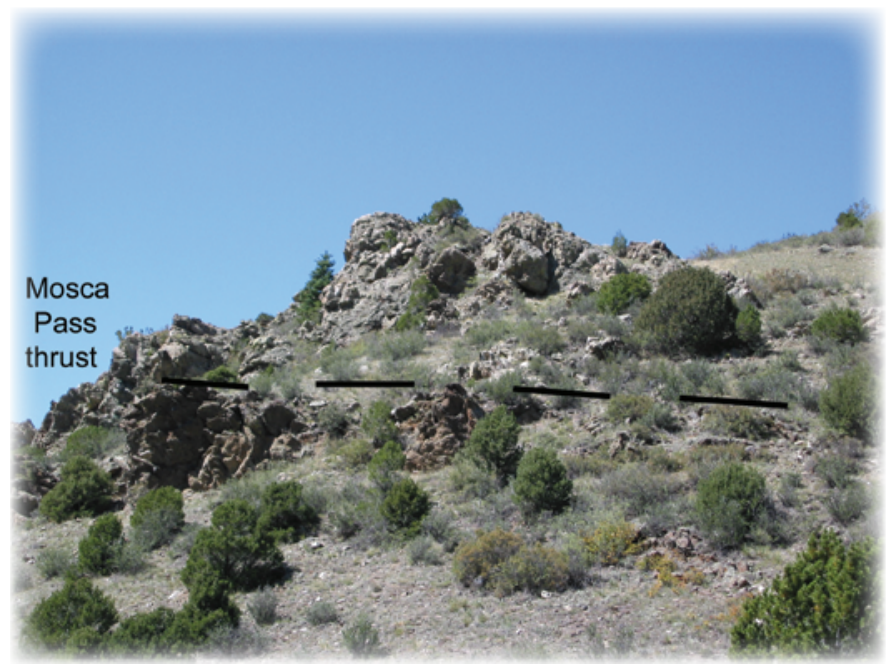

Figure 14. Photograph north of point 8 (lat $37.73148^{\circ} \mathrm{N}$. , long $105.47889^{\circ} \mathrm{W}$., elev. 9,270 feet), looking west across gulch from 100 feet north of the trail, showing the Mosca Creek thrust fault. The thrust (dashed line) lies at the contact between light-colored gneiss breccia (above) and dark reddish-brown sandstone of the lower member of the Minturn Formation. 
POINT 9: The Mosca Creek thrust fault crosses the trail about 0.3 mile east of point 8 (fig. 6). Between points 8 and 9 , the thrust breccia is exposed on the hillside all along the north side of Mosca Creek. The breccia is as much as 100 feet thick here and is developed entirely within gneiss above the thrust. It can be easily examined on the rocky hillside at point 9 where the trail leaves the trees along Mosca Creek and enters a small grassy area with scattered aspen (point 9, fig. 15A). Fractured and brecciated blocks of light- and dark-colored gneiss, pegmatite (a coarse-grained variant of granite), and dark igneous rocks have been mixed together by the intense grinding action of the thrust movement. The cliffs to the west are composed entirely of breccia. You have walked through the Mosca Creek window.
At point 9 you can examine the light-colored gneiss (fig. 15B) above the thrust breccia. This unit is exposed along the trail from here to the ridgeline at Mosca Pass. The lightcolored gneiss at Mosca Pass consists of mostly feldspar and quartz; it is metamorphosed granite. The gneiss is included with several bodies of rock referred to as the Twin Peaks pluton, a group of metamorphosed igneous intrusions named for Twin Peaks, south of Mosca Creek (see index map). The gneiss was formed by metamorphism of the granitic rocks of the pluton. Proceed another mile up the trail through lightcolored gneiss to the east entrance at Mosca Pass (fig. 16).

Two other types of gneiss also crop out around the Mosca Creek window. Gneiss resulting from metamorphism of intermediate-composition intrusions (feldspar-rich rocks
A

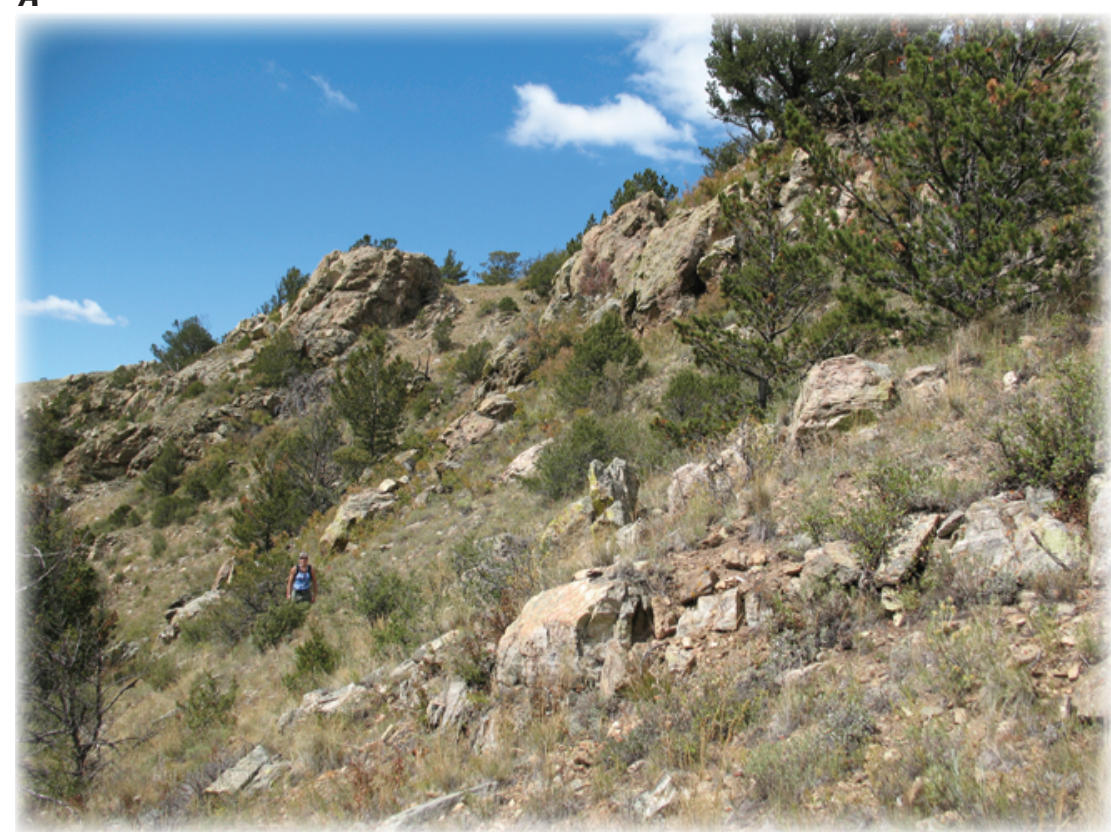

$\boldsymbol{B}$

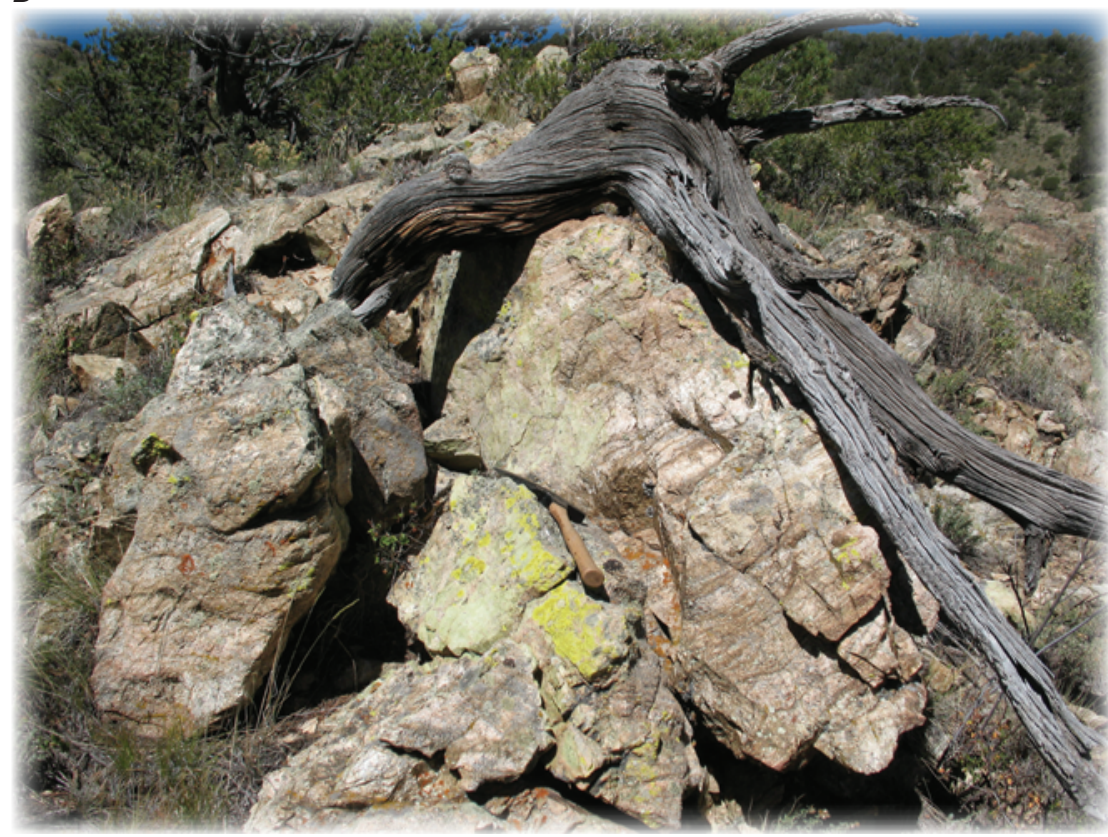

Figure 15. Photographs at point 9 (lat $37.73073^{\circ} \mathrm{N}$., long $105.47317^{\circ} \mathrm{W}$. , elev. 9,410 feet): $A$, Breccia zone in gneiss above the Mosca Creek thrust fault is exposed on this rocky hillside and in the cliffs beyond. The breccia here is as much as 100 feet thick. Person standing on the slope shows scale. $B$, Gneiss of Twin Peaks pluton immediately above breccia zone. Pick approximately 12 inches long shows scale. 


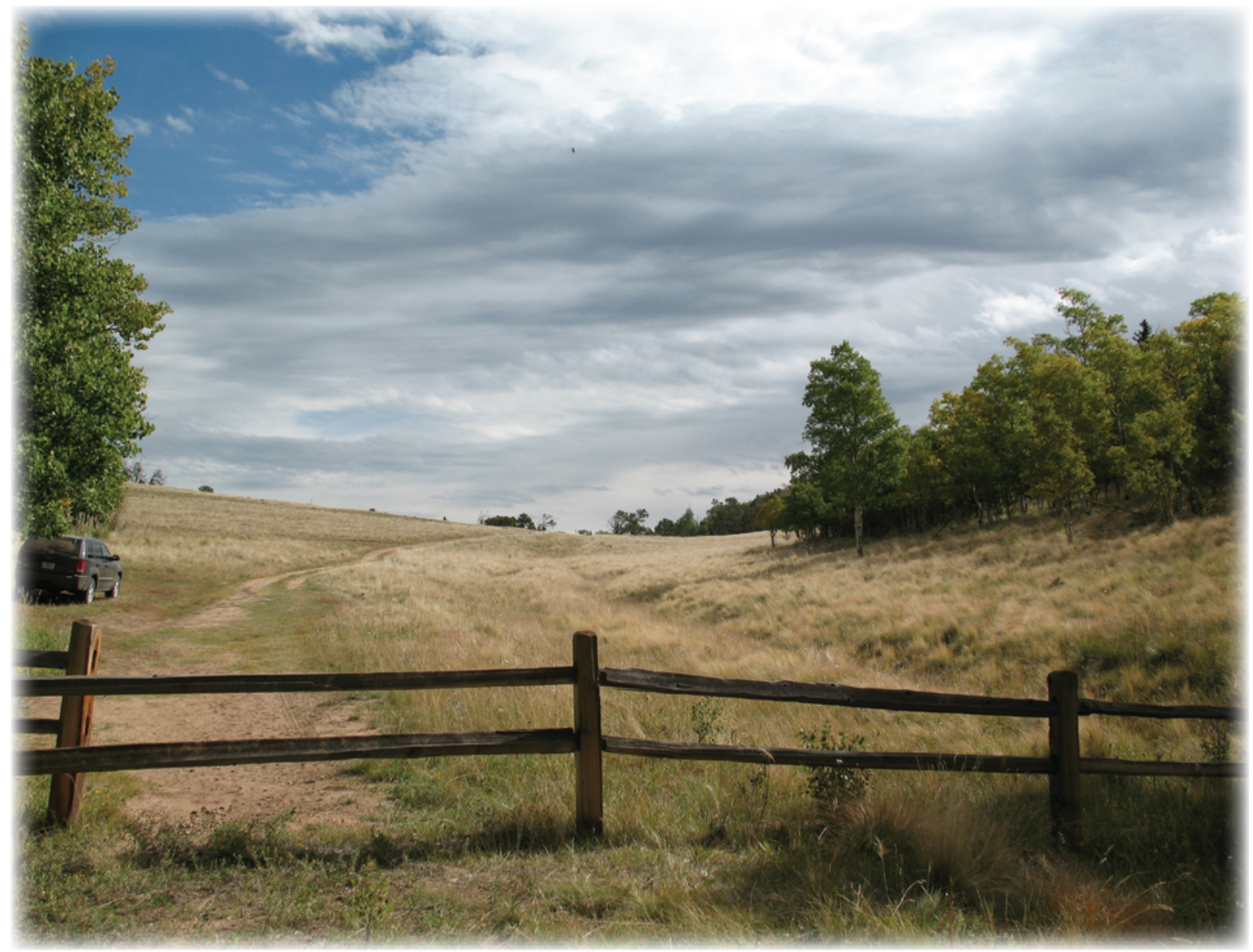

Figure 16. Mosca Pass from the east trailhead. Grassy areas are underlain by gneiss of the Twin Peaks pluton.

with less than 20 percent quartz, such as quartz monzonite) is exposed north and south of the Mosca Creek window along the west side of the range, and gneiss representing metamorphism of volcanic rocks crops out south of the window (fig. 2). Small dikes of pegmatite (coarse-grained igneous rock composed of quartz and feldspar) and amphibolite (a dark metamorphosed igneous rock composed mainly of amphibole minerals) cut through the gneiss.

\section{Magnetic Anomalies}

Most of the gneiss in the Sangre de Cristo Range contains small amounts of iron-bearing minerals that make it slightly magnetic. However, the light-colored gneiss at Mosca Pass may not be magnetic because it contains very few iron-bearing minerals. Sedimentary rocks (sandstone, siltstone, shale, and limestone) are also nonmagnetic. The Minturn Formation, a sedimentary rock, is exposed in the window beneath the Mosca Creek thrust and in Huerfano Park east of Mosca Pass, and the younger, overlying Sangre de Cristo Formation is exposed north of Mosca Pass. A folded section of the mile-thick Minturn Formation could produce a large negative magnetic anomaly under the range near Mosca Pass. The light-colored gneiss above the Mosca Creek thrust and the 1,000-footthick lower member of the Minturn Formation beneath the thrust in the Mosca Creek window (fig. $3 A$ ) are probably not thick enough to produce negative magnetic anomalies by themselves.

Magnetic intensity of different types of rocks in the range has been mapped by airborne surveys, which can also detect the magnetic intensity from rocks well below ground surface. These surveys show a positive magnetic anomaly centered between the mouths of Mosca and Morris Creeks on the west side of the range and a negative anomaly beneath the eastern half of the range and extending beneath the pediment to the east. The positive anomaly indicates that magnetic rock (possibly iron-bearing gneiss) underlies the western part of the range at Mosca Creek. The negative anomaly indicates that nonmagnetic rocks (light-colored, nonmagnetic gneiss or sedimentary rocks) underlie the eastern part of the range at Mosca Pass. This observation is explained if the east-side boundary fault dips west beneath the range and overrides a thick section of Minturn Formation as shown in the cross sections (fig. 3). 


\section{More Information}

The references cited below provide detailed information about the geology of the area around Mosca Creek; some of these may be accessible only through university libraries. You can find more information about the geologic history of the Sangre de Cristo Range in U.S. Geological Survey Circular 1349 (Lindsey, 2010). Two references (Reed and Ellis, 2009 and U.S. Geological Survey Geologic Names Committee, 2007) provide descriptions and definitions of geologic terms and geologic time.

\section{Acknowledgments}

We thank C. San Juan for help in preparing the geologic map and V.J.S. Grauch for sharing her knowledge of magnetic anomalies and their implications for cross sections in the Mosca Pass region. J.S. Caine and S.A. Minor provided helpful insights about the boundary fault east of the range. All are employees of the U.S. Geological Survey. We thank Fred Bunch, National Park Service, for a copy of the thesis by N.B. Aughenbaugh and for his assistance throughout this project. C.J. Fridrich, U.S. Geological Survey, and Danielle York, National Park Service, provided technical reviews. This work was supported by the U.S. Geological Survey Bradley Scholar program and the National Park Service.

\section{References Cited}

Aughenbaugh, N.B., 1958, Geology of the Sangre de Cristo Mountains at Mosca and Morris Creeks: Ann Arbor, Mich., University of Michigan, M.S. thesis, $40 \mathrm{p}$.

Bruce, R.M., and Johnson, B.R., 1991, Reconnaissance geologic map of parts of the Zapata Ranch and Mosca Pass quadrangles, Alamosa and Huerfano Counties, Colorado: U.S. Geological Survey Miscellaneous Field Studies Map MF-2168, scale 1:24,000.

Burford, A.E., 1960, Geology of the Medano Peak area, Sangre de Cristo Mountains, Colorado: Ann Arbor, Mich., University of Michigan, Ph.D. dissertation, 201 p.

Harlan, George, 1976, Postmarks and places: Denver, Colo., Golden Bell Press, 190 p.

Lindsey, D.A., 2010, The geologic story of Colorado's Sangre de Cristo Range: U.S. Geological Survey Circular 1349, 14 p. (Also available at http://pubs.usgs.gov/circ/1349/.)

National Park Service, 2011, Great Sand DunesHistory \& culture: National Park Service Website, accessed 11/08/2011, at http://www.nps.gov/grsa/historyculture/ index.htm.
Peterson, R.C., 1971, Glaciation in the Sangre de Cristo Range, Colorado, in James, H.L., ed., Guidebook to the San Luis Basin, Colorado, 22nd Field Conference, Sept. 30Oct. 1, 1971: Socorro, N. Mex., New Mexico Geological Society, p. 165-167.

Petit, J.P., 1987, Criteria for the sense of movement on fault surfaces in brittle rocks: Journal of Structural Geology, v. 9, no. $5 / 6$, p. 597-608.

Reed, Jack, and Ellis, Gene, 2009, Rocks above the clouds: Golden, Colo., Colorado Mountain Club Press, 240 p.

Rhodes, J.A., 1964, Stratigraphy and origin of PennsylvanianPermian rocks of the Huerfano Park quadrangle, Colorado: Ann Arbor, Mich., University of Michigan, Ph.D. dissertation, $176 \mathrm{p}$.

U.S. Geological Survey Geologic Names Committee, 2007, Divisions of geologic time-Major chronostratigraphic and geochronologic units: U.S. Geological Survey Fact Sheet 2007-3015, 2 p., available at http://pubs.usgs.gov/ $f_{s} / 2007 / 3015 /$.

Webster, R.J., 2000, Kinematic analysis and structural style of the Mosca Creek window, west side of the Sangre de Cristo Mountains, Alamosa County, Colorado: Wichita, Kans., Wichita State University, M.S. thesis, 164 p.

Winger, Charlie, and Winger, Diane, 2003, The essential guide to Great Sand Dunes National Park \& Preserve: Golden, Colo., Colorado Mountain Club Press, 239 p.

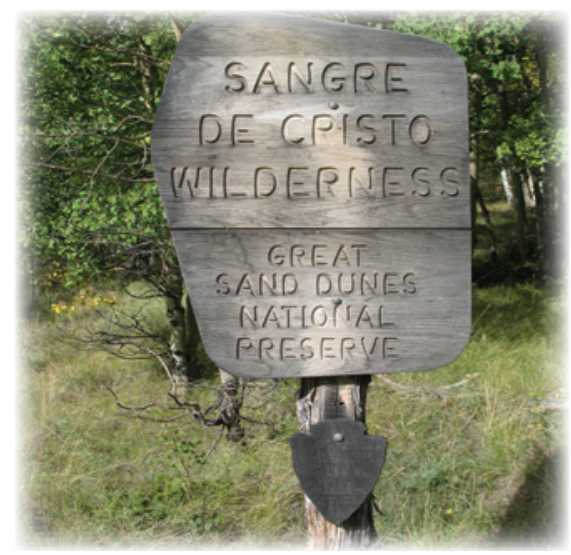

Publishing support provided by:

Denver Publishing Service Center

For more information concerning this publication, contact:

Center Director, USGS Central Mineral and Environmental Resources Science Center

Box 25046, Mail Stop 973

Denver, C0 80225

(303) 236-1562

Or visit the Central Mineral and Environmental Resources Science Center Web site at: http://minerals.cr.usgs.gov 
Front Cover. Mosca Creek window in foreground; Great Sand Dunes and Sangre de Cristo Range in background. Photograph from ridgeline summit, elevation 10,268 ft, by D.A. Lindsey.

Back Cover. Looking down Mosca Creek at Great Sand Dunes, by D.A. Lindsey. 


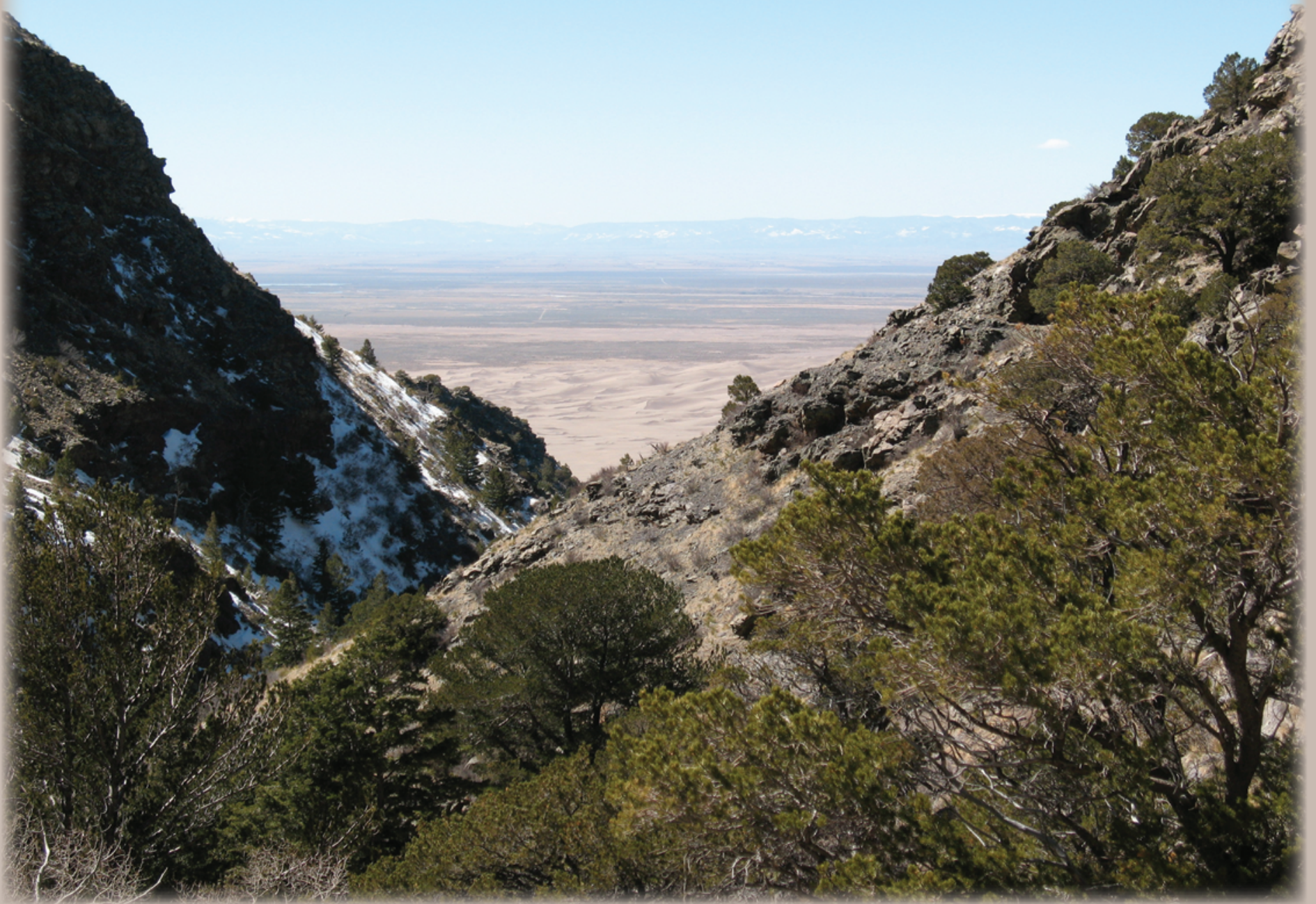

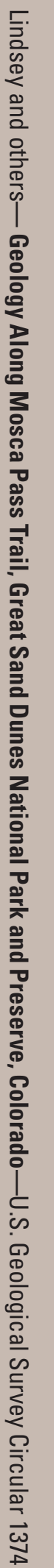

